\title{
COMPARATIVE STUDY OF SIX MAIZE (ZEA MAYS L.) CULTIVARS CONCERNING CADMIUM UPTAKE, PARTITIONING AND TOLERANCE
}

\author{
AKRAM, M. A. ${ }^{1,2}$ - WAHID, A. ${ }^{2}$ - ABRAR, M. ${ }^{1}$ - MANAN, A. ${ }^{1}$ - NAEEM, S. ${ }^{3}$ - ZAHID, M. A. ${ }^{4}-$ \\ GILANI, M. M. $.^{5}-$ PAUDYAL, R. ${ }^{6}-$ GONG, H. Y. ${ }^{1}-$ RAN, J. Z. $^{1^{*}}-$ DENG, J. M. ${ }^{1 *}$ \\ ${ }^{1}$ State Key Laboratory of Grassland Agro-Ecosystem, School of Life Sciences, Lanzhou \\ University, Lanzhou, Gansu 730000, China \\ ${ }^{2}$ Department of Botany, University of Agriculture, Faisalabad-38040, Pakistan
}

${ }^{3}$ Gansu Key Laboratory of Biomonitoring and Bioremediation for Environmental Pollution, School of Life Sciences, Lanzhou University, Lanzhou, Gansu 730000, China

${ }^{4}$ National Institute for Biotechnology and Genetic Engineering (NIBGE), Faisalabad, Pakistan

${ }^{5}$ Forestry College, Fujian Agriculture and Forestry University, Fuzhou 350002, Fujian Province, China

${ }^{6}$ State Key Laboratory of Cryospheric Science, Northwest Institute of Eco-Environment and Resources, Chinese Academy of Sciences, Lanzhou 730000, China

\author{
*Corresponding authors \\ e-mail:ranjz@lzu.edu.cn;dengjm@lzu.edu.cn
}

(Received $14^{\text {th }}$ Dec 2020; accepted $18^{\text {th }}$ Mar 2021)

\begin{abstract}
This experiment was conducted to determine $\mathrm{Cd}$ accumulation, partitioning, translocation and their ultimate consequences on growth and biochemical traits of six maize cultivars to screen out $\mathrm{Cd}$ tolerant one. A significant decrease in growth and biochemical traits as well as in Cd tolerance index was found, especially at higher $\mathrm{Cd}$ level. Moreover, the varieties and $\mathrm{Cd}$ treatments were found significant for the growth and biochemical traits. Uptake of $\mathrm{Cd}, \mathrm{Ca}, \mathrm{K}$ and $\mathrm{P}$ in the different plant tissues were significantly affected by the varieties and $\mathrm{Cd}$ treatments. Translocation, bioconcentration and bioaccumulation factors were found non-significant for varieties and $\mathrm{Cd}$ treatments. A significant positive correlation was found between growth and biochemical traits while, among plant total $\mathrm{Cd}, \mathrm{Ca}, \mathrm{K}$ and $\mathrm{P}$, total plant dry; and fresh weight and plant height were significantly negative. Furthermore, the PC1 was loaded by growth traits; $\mathrm{Ca}, \mathrm{K}$ and $\mathrm{P}$ while $\mathrm{PC} 2$ by the $\mathrm{Cd}$ in different plant tissues. Hence, a strong negative correlation was observed between the $\mathrm{PC} 1$ and $\mathrm{PC} 2$ parameters. The maximum $\mathrm{Cd}$ accumulation was in the roots rather than the crown and leaf tissues of maize cultivars. The EV-1098 was to be more tolerant to $\mathrm{Cd}$ stress than other cultivars.
\end{abstract}

Keywords: heavy metal toxicity, growth and biochemical traits, varietal differences, tolerance index, bioconcentration factor

\section{Introduction}

Life and biodiversity are significantly affected by the accumulation of heavy metals in soils either by natural processes or by human activities. The toxicity of heavy metals is one of the major reasons of environmental and ecological issues (Roy et al., 2018). The rise of heavy metal contamination in agricultural fields and soils caused primarily by anthropogenic activities resulted in their incorporation into the grown crops and ultimately into the food chain (Siebers et al., 2014; Retamal-Salgado et al., 2017). A 
large number of industries produce wastewater containing significant concentrations of heavy metals which is discharged into drains and rivers. These wastewater effluents contain a large number of heavy metals such as $\mathrm{Cr}, \mathrm{Cd}, \mathrm{Cu}, \mathrm{Pb}, \mathrm{Zn}$, and $\mathrm{Ni}$ that have a major impact on crops and their yields (Najam et al., 2015; Ali et al., 2020). The long-term irrigation with industrial wastewater allows heavy metals to persist in the soil, which increases their absorption and accumulation by the plants which ultimately enter into the food chain (Najam et al., 2015). Several non-essential heavy metals even in traces induce toxicity in plants and affect the growth of several crops (Marquez et al., 2018). Heavy metals such as $\mathrm{Cd}, \mathrm{Ni}, \mathrm{Pb}, \mathrm{Cu}, \mathrm{Cr}$ and $\mathrm{Zn}$ not only negatively affect the growth and development of plants but also disturb the micro-flora of the soils (Abdu et al., 2017). To achieve the goals of a sustainable environment and agriculture it is necessary to control heavy metal pollution on a priority basis (Naveed et al., 2020).

$\mathrm{Cd}$ is a poisonous, non-degradable and non-essential heavy metal that naturally exists in most of the soil types (Naveed et al., 2020). Its naturally occurring levels are usually $<1 \mathrm{mg} / \mathrm{kg}$, but these levels have increased to $1000 \mathrm{mg} / \mathrm{kg}$ in some geographical regions because of haphazard urbanization/ industrialization in the last two centuries (Coakley et al., 2019). Cd exposures can be toxic or even lethal to plants in certain cases even at concentrations as low as $2.5 \mathrm{mg} / \mathrm{kg}$ (Henson et al., 2013). The anthropogenic activities increasing $\mathrm{Cd}$ concentration in the environment are manure (sewage sludge), combustion of fossil fuel, iron foundries, electroplating, smelting, waste disposal of water and usage of synthetic industrial products such as paints, pesticides and sludge (Anjum et al., 2015; Rizwan et al., 2017; Abedi and Mojiri, 2020). Interestingly, physiochemical properties of $\mathrm{Cd}$ are similar to other micronutrients such as $\mathrm{Zn}$, which enable it to be taken up readily by plants and crops (Coakley et al., 2019). Cd salts are comparatively more soluble than others in the soil, consequently, $\mathrm{Cd}$ can readily be incorporated into the natural environment and easily accumulated in the roots and other edible parts of the plants (Naveed et al., 2020). Plants can easily transport Cd to different parts through the vascular tissues (xylem and phloem) (Ismael et al., 2019). The $\mathrm{Cd}$ has a greater absorption and accumulation rate than other heavy metals like $\mathrm{Cu}$ and $\mathrm{Zn}$ (Liao et al., 2019). It alters the physiological functions by disturbing many metabolic processes including nitrogen metabolism (Roy et al., 2016; Abedi and Mojiri, 2020). Cd absorption and accumulation depends upon the age of plants (Godinho et al., 2018) and its deposition gradually increases with time, affecting consumers directly or indirectly (Abedi and Mojiri, 2020). Daily consumption of $1 \mathrm{mg} / \mathrm{kg}$ (body weight) Cd is considered harmful to humans (Retamal-Salgado et al., 2017). The long-term exposure and ingestion of Cd-contaminated food is toxic to the food chain and poses a severe health risk to human. It is highly imperative that $\mathrm{Cd}$-polluted soils be remedied to preserve and restore the ecological functionality of these soils (Naveed et al., 2020).

Accumulation of $\mathrm{Cd}$ in edible parts of the plant is more harmful than the overall plant intake. While certain techniques are being used to reduce the $\mathrm{Cd}$ in the food chain (Rai et al., 2019). Cd toxicity can negatively affect biomass, chlorophyll contents, number of leaves/flowers/fruits, leaf area, crop yield of plants and its ability to uptake essential nutrients (Ghani, 2010; Coakley et al., 2019). Cd accumulation is directly related to its applied concentration and exposure time (Rolli et al., 2010). Cd affects the lateral roots in maize, changes the root color and roots become stiff. It also decreases the coleoptiles size, causes chlorosis, and ultimately necrosis (Shafi et al., 2010; Kaznina and Titov, 2014). The increased $\mathrm{Cd}$ concentration amplified the $\mathrm{Cd}$ absorption in the shoots of maize (Nguyen et al., 2016) while roots accumulate more Cd than shoots (Stritsis and 
Claassen, 2013). Cd translocation from roots to shoots is limited by the plants of the Poaceae family in order to maintain the nutritional balance that is disturbed by the $\mathrm{Cd}$ induction, e.g., by the suberization of endoderm cells and lignification of root cortex cells (Kaznina and Titov, 2014). The main symptoms of Cd toxicity including stunted growth, enzyme activation or deactivation, photosynthetic activity and plant-water relationship disturbance (Raza et al., 2020). The plant species and varieties vary for $\mathrm{Cd}$ accumulation and translocation as well as Cd partitioning into their different tissues (Yang et al., 2014; Coakley et al., 2019), such as apple (Zhou et al., 2017), maize (Shah et al., 2016; Rizwan et al., 2017), mungbean (Ghani, 2010), mustard and oats (BorosLajszner et al., 2020), pea (Naveed et al., 2020), rice (Fahad et al., 2015; Marquez et al., 2018), sorghum (Roy et al., 2016) and wheat (Shafi et al., 2010; Abedi and Mojiri, 2020). The varied distribution of $\mathrm{Cd}$ at the cellular/subcellular level in different organs was attributed to the high accumulation capacity of plants (Coakley et al., 2019). Plants have adapted different mechanisms for Cd tolerance and to mitigate its toxic effects, such as maize compartmentalizes $\mathrm{Cd}$ as a mechanism of tolerance in the cell wall of stems (Akhter et al., 2014).

Maize (Zea mays L.) is a cereal crop grown worldwide belonging to grasses (Poaceae). It is known as a heavy metal tolerant and accumulator because of its survival ability in the metal-polluted soils and metal accumulation capacity. Some maize genotypes show tolerance to heavy metal toxicity (Rizwan et al., 2017) and Cd contaminated soils (Van Slycken et al., 2013). Due to this property maize is potentially used plant for phytoremediation, especially in Cd-contaminated soils (Huang et al., 2020; Raza et al., 2020). Plant tolerance to heavy metals largely depends on the efficiency of uptake, translocation, and sequestration in specialized tissues and cell organelles (Boros-Lajszner et al., 2020). Maize is commonly used for glucose preparation, edible oil production and several other products (Shah et al., 2016). The maize is also one of the highest growing crops and has the survival ability in the metalpolluted soils and metal accumulation capacity concerning other crops (Wuana and Okieimen, 2010). Maize is considered among 400 plants that accumulate heavy metals and survive in Cd-polluted soils but maybe with low biomass production (Waseem et al., 2014). The maize production is decreasing due to the heavy metal accumulation in soils. Therefore, to find the resistant maize varieties are necessary to fulfill the food requirement of the worldwide increasing population.

Pakistan is one among the agricultural countries in the world and its large population (> 70\%) living in the villages directly or indirectly depends on agriculture (Bashir et al., 2012). Pakistan is the $20^{\text {th }}$ largest producer of maize in the world. However, rapid urbanization and an increase in population demand healthier and higher crop yields of rice, sugarcane, wheat and maize (Ali et al., 2017). In Pakistan, the vegetables and crops are commonly irrigated with canal water that gets polluted by industrial wastes when passing by industrial areas, which is commonly contaminated with heavy metals (Naveed et al., 2020). Among these heavy metals, $\mathrm{Cd}$ is of major concern. Maize fabrication is significantly reduced in Pakistan owing to the use of sewage water (Waseem et al., 2014). Industrial wastewater is extensively used for irrigation in the agricultural areas of Pakistan. The wide distribution of $\mathrm{Cd}$ in wastewater has been reported in the different areas of Pakistan (Waseem et al., 2014; Najam et al., 2015). The maximum amount of $\mathrm{Cd}(5.35 \mathrm{mg} / \mathrm{L})$ in wastewater was recorded in the Korangi region of Karachi (Amin et al., 2014), which exceeded the $0.10 \mathrm{mg} / \mathrm{L}$ permissible threshold set by NEQS-Pak (Waseem et al., 2014). In addition, the Cd concentration in 
wastewater was also found above the said threshold limit in the Punjab province $(0.18$ to $0.37 \mathrm{mg} / \mathrm{L}$ ) (Mahmood and Malik, 2014) and the Khyber Pakhtunkhwa (KPK) province (0.19 to $0.62 \mathrm{mg} / \mathrm{L}$ ) (Rehman et al., 2008).

Thus, in this context, it is urgent to investigate the strategies to reduce the bioavailability of these heavy metals for plants, particularly crops and vegetables. Moreover, it is also required to find out the Cd-tolerant varieties. There are few reports on the varietal differences for accumulation, translocation and partitioning of $\mathrm{Cd}$ in different plant tissues (DPT) under induced Cd toxicity. So, the present study was conducted: 1) To screen out the Cd tolerant variety and to investigate the varietal performance of maize to induced Cd toxicity; 2) To determine the extent of the accumulation, partitioning and translocation of $\mathrm{Cd}$ in different parts (crown tissue, leaves and roots) of maize varieties, and 3) To estimate the consequence of $\mathrm{Cd}$ appliance on the growth and biochemical traits of various maize varieties.

\section{Materials and Methods}

\section{Study location}

The experiment was conducted in the rain protected warehouse of the Old Botanical Garden, University of Agriculture, Faisalabad-Pakistan under natural conditions. The geographical location of the experimental site is $31^{\circ} 45^{\prime} \mathrm{N}, 73^{\circ} 14^{\prime} \mathrm{E}$ at $180 \mathrm{~m}$ above the sea level with a semi-arid climate. The mean annual precipitation and evaporation are $375 \mathrm{~mm}$ and $1600 \mathrm{~mm}$, respectively. The mean annual temperature is $24.8^{\circ} \mathrm{C}$ and the temperature normally ranges from $50^{\circ} \mathrm{C}$ to $4^{\circ} \mathrm{C}$ in the summer and winter season, respectively (Akram, 2020).

\section{Experimental details}

The experiment was designed to assess the $\mathrm{Cd}$-accumulation in different maize parts: crown tissue (CT), leaves (L) and roots (R) and to check the effect of Cd-toxicity on growth and biochemical traits as well as the growth response of maize cultivars. The seeds of six maize cultivars (EV-1098, Sahiwal-2002/SA-2002/Sahiwal, EV-5098, Agati-2002/AG-2002/Agaiti, EV-6098, and Sadaf) were obtained from the Maize and Millets Research Institute (MMRI), Yusafwala, Sahiwal District, Pakistan. The 20 seeds per pot were sown in the plastic pots $(20 \mathrm{~cm}$ diameter $\times 28 \mathrm{~cm}$ height $)$ that filled with $10 \mathrm{~kg}$ of river sand. The sand was thoroughly washed with tap water and then thrice with distilled water before filling in the pots. The pots were placed in the warehouse under natural conditions of light and temperature. The experiment was arranged in a Completely Randomized Design (CRD) with a factorial arrangement.

\section{Treatment application}

Three different Cd-concentrations $(0,500$ and $1000 \mu \mathrm{M})$ were made by dissolving cadmium chloride $\left(\mathrm{CdCl}_{2} .2 .5 \mathrm{H}_{2} \mathrm{O}\right)$ of Merck Company in distilled water. After seeds germination (three days), the seedlings were thinned to keep 5 uniform and healthy seeds per pot. Then, the plants were irrigated with Hoagland's nutrient containing solution (Hoagland and Arnon, 1950; Zhang et al., 2020) for a regular period of three days, until the completion of the experiment. After that, the 28-days old plants of all the varieties were treated with enhanced $\mathrm{Cd}$-concentrations $(0,500$ and $1000 \mu \mathrm{M}$ solution) after every three-day interval seven times. Two factors (there different Cd- 
concentrations and six maize cultivars) were combined to make 18-treatment and each treatment was replicated thrice (54-pots). Only the water was supplied to the control plants. The Cd-treated and control plants were grown for another 21-day.

\section{Growth traits}

After 21 days of Cd-treatment, the morphological parameters such as the number of leaves, shoot length (SL), root length (RL), shoot fresh weight (SFW), root fresh weight (RFW), shoot dry weight (SDW), root dry weight (RDW) and stem diameter (SD) was recorded. Before uprooting, the shoot length (SL), the number of green leaves per plant (NOL) and stem diameter (SD) of each plant was measured. The SL was measured from the stem base to the top of the plant. The NOL for each treatment was counted and means values were calculated from three replicates. The SD was measured with Vernier Calliper. The RL was measured from the bottom of the plant to the stem base. After that, all the plants were harvested. The SFW and RFW of three plants per replicate were recorded immediately after uprooting the plants and the mean value per plant was calculated. Then, washed with distilled water twice, blotted dry and transferred to paper bags and stored for $24-48$ hours in an oven set at $65^{\circ} \mathrm{C}$ and used for subsequent analysis.

\section{Digestion of plant material for chemical analysis and determination of $\mathrm{K}^{+}, \mathrm{Ca}^{2+}, \mathrm{P}$ and $\mathrm{Cd}^{2+}$}

The plant parts including crown tissue (CT), leaves (L) and roots $(\mathrm{R})$ were separated and shade dried to determine the $\mathrm{K}^{+}, \mathrm{Ca}^{2+}$, phosphorus (P) and cadmium $\left(\mathrm{Cd}^{2+}\right)$ contents. $0.5 \mathrm{~g}$ dried well ground plant material and $5 \mathrm{~mL}$ of Conc. $\mathrm{HNO}_{3}$ was taken in digestion flasks and incubated overnight at room temperature. Then, $0.5 \mathrm{~mL}$ of $\mathrm{HNO}_{3}$ was added into each digestion flask to boost the reaction and the flasks were placed on the hot plate. The temperature was gradually increased up to $200^{\circ} \mathrm{C}$ for $30-45$ minutes until the complete transparent digestion. After cooling the flasks, the extract was filtered by filter paper and the volume was raised to $50 \mathrm{~mL}$ by adding distilled $\mathrm{H}_{2} \mathrm{O}$ in the volumetric flask and used for the determination of $\mathrm{K}^{+}, \mathrm{Ca}^{2+}, \mathrm{P}$ and $\mathrm{Cd}^{2+}$.

The potassium $\left(\mathrm{K}^{+}\right)$and calcium $\left(\mathrm{Ca}^{2+}\right)$ contents were recorded using Flame Photometer (Jenway PFP7). Phosphorus (P) was determined by the ammonium molybdate method (Sparks et al., 1996; Akram et al., 2020). The $\mathrm{Cd}^{2+}$ amount in different plant parts was determined by the atomic absorption spectrophotometer (AAS) (Perkin Elmer Analyst-100).

\section{Data analysis}

The following indices were determined.

\section{Bioconcentration factor $(B C F)$ and transportation index $(\mathrm{Ti})$}

Cadmium uptake was assessed by the bioconcentration factor (BCF) and bioaccumulation factor (BAF). The concentrations of plant and soil/substrate $\mathrm{Cd}$ was determined according to dry weight. BCF and BAF indicate the plant's ability to accumulate a specific metal regarding its concentration in the growing medium/substrate. They were calculated by the following formulas (Retamal-Salgado et al., 2017):

$$
\mathrm{BAF}_{\mathrm{CT}}=\frac{\mathrm{C}_{\mathrm{CdCT}}}{\mathrm{C}_{\text {Substrate }}}
$$




$$
\begin{aligned}
& \mathrm{BAF}_{\mathrm{L}}=\frac{\mathrm{C}_{\mathrm{CdL}}}{\mathrm{C}_{\text {Substrate }}} \\
& \mathrm{BCF}_{\mathrm{R}}=\frac{\mathrm{C}_{\text {CdR }}}{\mathrm{C}_{\text {Substrate }}}
\end{aligned}
$$

where $\mathrm{C}_{\mathrm{CdCT}}, \mathrm{C}_{\mathrm{CdL}}$, and $\mathrm{C}_{\mathrm{CdR}}$ are the concentrations of $\mathrm{Cd}$ in the crown tissue, leaves, and roots, respectively; and $\mathrm{C}_{\text {Substrate }}$ in the growing medium/substrate.

\section{Translocation factor $(T F)$}

The translocation factor (TF) gives the aerial parts/root concentration of metal and shows the plant's ability to transfer the metal from plant roots to the aerial parts (crown tissue and leaves). TF was calculated by the following formulas (Retamal-Salgado et al., 2017):

$$
\begin{gathered}
\mathrm{TF}_{\mathrm{CT}}=\frac{\mathrm{C}_{\mathrm{CdCT}}}{\mathrm{C}_{\mathrm{CdR}}} \\
\mathrm{TF}_{\mathrm{L}}=\frac{\mathrm{C}_{\mathrm{CdL}}}{\mathrm{C}_{\mathrm{CdR}}}
\end{gathered}
$$

where $\mathrm{C}_{\mathrm{CdCT}}, \mathrm{C}_{\mathrm{CdL}}$, and $\mathrm{C}_{\mathrm{CdR}}$ are the concentrations of $\mathrm{Cd}$ in the crown tissue, leaves, and roots, respectively.

\section{Tolerance index (TI)}

The tolerance index (TI) shows the plant's ability to tolerate Cd toxicity. TI was calculated using the following equation (Retamal-Salgado et al., 2017):

$$
\mathrm{TI}=\frac{\mathrm{DBM}_{\mathrm{Cd}-\text { treatments }}}{\mathrm{DBM}_{\text {Control }}}
$$

where $\mathrm{DBM}_{\mathrm{Cd}-\text { treatments }}$ and $\mathrm{DBM} \mathrm{M}_{\mathrm{Control}}$ are the dry biomass $(\mathrm{DBM})$ of each $\mathrm{Cd}$ treatment and $\mathrm{DBM}$ of the control treatment (no added $\mathrm{Cd}$ ), respectively.

\section{Statistical analysis}

To confirm the data variability and result's validity, all the data were analyzed at two levels. Firstly, all the data were used to treat all observations at the same time by principal component analysis (PCA) to assess the correlation among all the plant traits, Cd-treatments and growth parameters. Secondly, the data were analyzed at the variety level for each plant trait, Cd-treatments and plant parts. Tukey's test was conducted to observe the significant differences within-and-between Cd-treatment means. The Pearson correlations were conducted using the "lm" function in the R package (Akram et al., 2020). Mean values of the $\mathrm{Ca}^{2+}, \mathrm{K}^{+1}, \mathrm{P}$ and $\mathrm{Cd}^{2+}$ in different plant parts (crown tissue, leaves and roots) were mapped against each cultivar to observe the whole data patterns. The linear regressions were constructed to assess the bivariate relationship between different plant traits and parts of all the cultivars. All the values in figures and tables expressed as mean (triplicate) \pm standard error (SE) and the values were considered significant at $\mathrm{p}<0.05$. All the statistical data were arranged in Excel sheets and analyzed using SPSS 21.0 and R software (version 3.6.0, R Development Core Team 2018). 


\section{Results}

\section{Effect of Cd on the plant biomass and related growth traits}

Varieties and $\mathrm{Cd}$ treatments were found to be significant for all the growth traits, such as shoot fresh weight (SFW), root fresh weight (RFW), shoot dry weight (SDW), root dry weight (RDW), shoot length (SL), root length (RL), stem diameter (SD) and the number of leaves plant $^{-1}$ (NOL) (Table 1). The SFW, RFW, SDW, RDW, SL, RL, SD and NOL interacted and significantly changed with the Cd treatments (Figs. S1, S2). Under control conditions, the varietal effect of all the growth traits was noted significantly different for all the six varieties, which exhibited EV-1098 as the highest biomass yielding and SA-2002 lowest biomass yielding variety among all other varieties (Table 1; Figs. S1, S2). The EV-1098 performed better for all traits than other varieties. However, the biomass and all the other growth-related traits showed a significant decreasing trend for all the six varieties with an increased level of $\mathrm{Cd}$. The reduction in the SFW, RFW, SDW, RDW, SL, RL, SD and NOL was recorded $56 \%$, $45 \%, 34 \%, 30 \%, 61 \%, 45 \%, 35 \%$ and $63 \%$ (from control level), respectively. Maximum reduction was found in the NOL and minimum in the RDW, 63\% and 30\% reduction from the control level, respectively. All the varieties and treatments were found significant, while variety $(\mathrm{V}) \times$ treatment $(\mathrm{T})$ interactions were noted non-significant for all the growth traits, except stem diameter (SD) (Table 1). Significant positive correlations were observed between the different growth traits (Fig. S3).

Table 1. Shoot fresh weight (SFW), root fresh weight (RFW), shoot dry weight (SDW), root dry weight $(R D W)$, shoot length $(S L)$, root length $(R L)$, stem diameter $(S D)$ and the number of leaves per plant (NOL) for the different $C d$ treatments

\begin{tabular}{|c|c|c|c|c|c|c|c|c|c|}
\hline Traits & & SFW & RFW & SDW & RDW & SL & RL & SD & NOL \\
\hline \multirow{6}{*}{$\begin{array}{c}\text { Maize } \\
\text { varieties } \\
\text { (V) }\end{array}$} & EV-1098 & $32.95 \mathrm{a}$ & $24.04 \mathrm{a}$ & $9.19 \mathrm{a}$ & $5.63 \mathrm{a}$ & $67.87 \mathrm{a}$ & $45.67 \mathrm{a}$ & $0.54 \mathrm{a}$ & $4.56 \mathrm{a}$ \\
\hline & SA-2002 & $23.45 \mathrm{~d}$ & $20.00 \mathrm{~b}$ & $6.38 c$ & $3.70 \mathrm{c}$ & $54.25 \mathrm{~d}$ & $30.83 \mathrm{e}$ & $0.36 \mathrm{~d}$ & $4.22 \mathrm{ab}$ \\
\hline & EV-5098 & $25.89 \mathrm{bcd}$ & $16.53 \mathrm{c}$ & $6.93 c$ & $3.90 \mathrm{c}$ & $57.93 \mathrm{~cd}$ & $33.69 \mathrm{de}$ & $0.39 \mathrm{~cd}$ & $3.78 \mathrm{ab}$ \\
\hline & AG-2002 & 29.89ab & $22.43 \mathrm{ab}$ & $8.41 \mathrm{ab}$ & $5.12 \mathrm{ab}$ & $63.77 \mathrm{ab}$ & $42.70 \mathrm{ab}$ & $0.49 \mathrm{~b}$ & $3.44 \mathrm{~b}$ \\
\hline & EV-6098 & $24.52 \mathrm{~cd}$ & $19.84 b$ & $7.58 b c$ & $4.49 b c$ & $59.76 b c$ & $39.91 b c$ & $0.42 \mathrm{c}$ & $3.89 \mathrm{ab}$ \\
\hline & Sadaf & $28.51 \mathrm{abc}$ & $21.95 \mathrm{ab}$ & $7.30 \mathrm{bc}$ & $4.12 \mathrm{c}$ & $61.19 b c$ & $37.14 \mathrm{~cd}$ & $0.43 \mathrm{c}$ & $4.11 \mathrm{ab}$ \\
\hline \multirow{3}{*}{$\begin{array}{c}\text { Treatments } \\
\text { (T) }\end{array}$} & $\begin{array}{c}\text { To } \\
\text { (Control) }\end{array}$ & $34.71 \mathrm{a}$ & $26.95 \mathrm{a}$ & $10.98 \mathrm{a}$ & $6.41 \mathrm{a}$ & $73.33 \mathrm{a}$ & $52.49 \mathrm{a}$ & $0.63 \mathrm{a}$ & $5.00 \mathrm{a}$ \\
\hline & $\begin{array}{c}\mathrm{T} 1(500 \\
\mu \mathrm{M})\end{array}$ & $28.34 \mathrm{~b}$ & $20.24 b$ & $8.20 \mathrm{~b}$ & $5.11 \mathrm{~b}$ & $64.12 b$ & $39.00 \mathrm{~b}$ & $0.46 \mathrm{~b}$ & $3.83 \mathrm{~b}$ \\
\hline & $\begin{array}{c}\mathrm{T} 2(1000 \\
\mu \mathrm{M})\end{array}$ & $19.56 \mathrm{c}$ & $15.20 \mathrm{c}$ & $3.71 \mathrm{c}$ & $1.95 \mathrm{c}$ & $44.95 \mathrm{c}$ & $23.48 \mathrm{c}$ & $0.22 \mathrm{c}$ & $3.17 \mathrm{c}$ \\
\hline \multirow{3}{*}{ ANOVA } & $\mathrm{V}$ & $* * *$ & $* * *$ & $* * *$ & $* * *$ & $* * *$ & $* * *$ & $* * *$ & $*$ \\
\hline & $\mathrm{T}$ & $* * *$ & $* * *$ & $* * *$ & $* * *$ & $* * *$ & $* * *$ & $* * *$ & $* * *$ \\
\hline & $\mathrm{V} \times \mathrm{T}$ & ns & ns & ns & ns & ns & ns & $*$ & ns \\
\hline
\end{tabular}

Different letters in the same column indicate the significant differences compared with Cd treatments and maize varieties according to Tukey's test $(p<0.05)$

\section{Cd uptake, translocation, partitioning and its effect on the different biochemical traits}

The uptake of cadmium in the crown tissue (CT) was significantly affected by the varieties $(\mathrm{V})$, Cd treatments $(\mathrm{T})$ and interaction between them $(\mathrm{V} \times \mathrm{T})($ Table 2; Fig. S4). The contrast to different Cd levels (Table 2), the maximum $\mathrm{Cd}$ accumulation was 
noted with $1000 \mu \mathrm{M} \mathrm{CdCl}_{2}$. While the contrast between different varieties (Table 2), the highest uptake of $\mathrm{Cd}$ in the crown tissue was recorded in two varieties, such as SA-2002 and EV-6098 (0.10 $\left.\mathrm{mg} \mathrm{g}^{-1}\right)$ the same amount of $\mathrm{Cd}$ in both varieties; and the lowest $\mathrm{Cd}$ uptake was found in the EV-1098 $\left(0.03 \mathrm{mg} \mathrm{g}^{-1}\right)$ variety with significant differences (Table 2, Fig. 1).

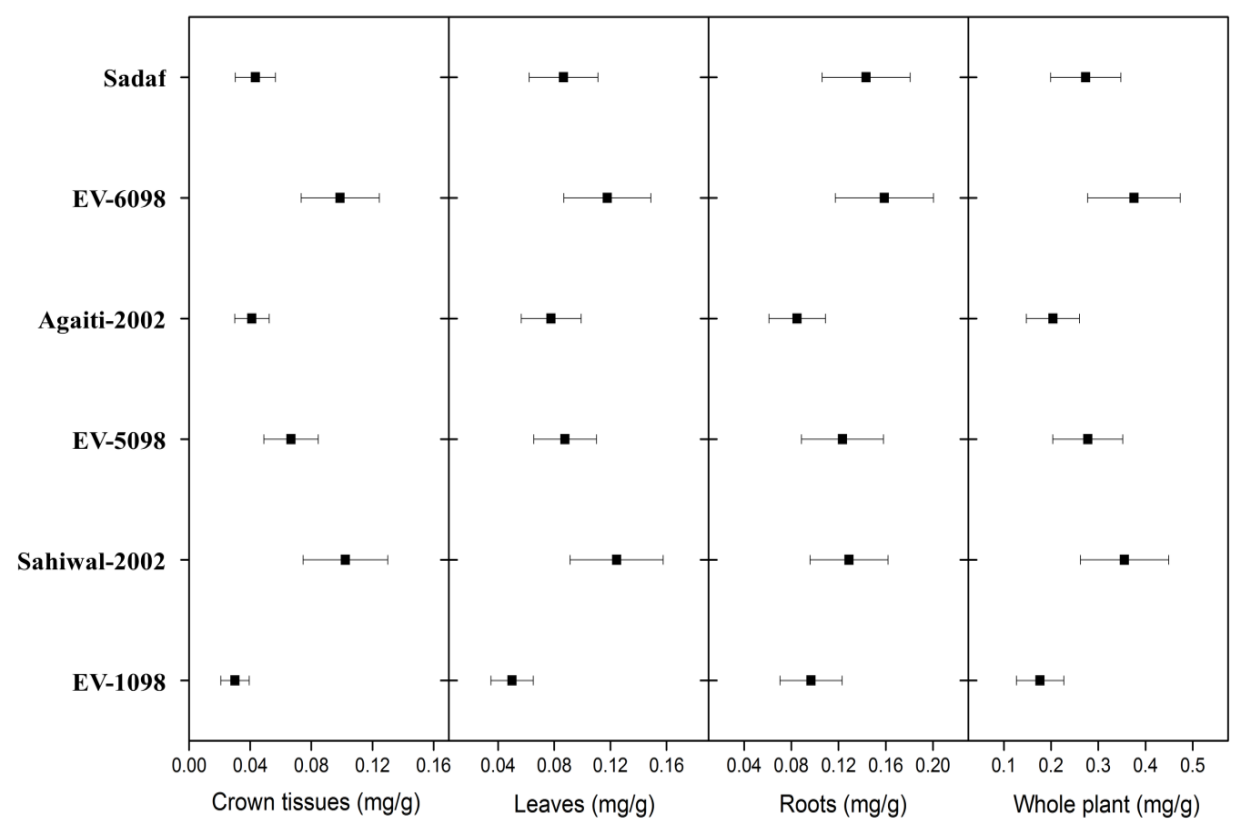

Figure 1. The concentration of $C d$ (mean $\pm S E$ ) in the different plant parts of the six maize varieties

The Cd uptake in the leaves (L) was substantially influenced by the varieties (V), Cd treatments $(\mathrm{T})$ and interaction between them $(\mathrm{V} \times \mathrm{T})\left(\right.$ Table 2). In comparison to $\mathrm{CdCl}_{2}$ levels (Table 2; Fig. S4), the significant higher uptake of Cd was observed with 1000 $\mu \mathrm{M} \mathrm{CdCl}_{2}\left(0.17 \mathrm{mg} \mathrm{g}^{-1}\right)$ followed by $500 \mu \mathrm{M} \mathrm{CdCl}_{2}\left(0.11 \mathrm{mg} \mathrm{g}^{-1}\right)$. The contrasting between different varieties (Table 2), it was noted that the significantly higher amount of Cd has accumulated in the leaves of the SA-2002 $\left(0.12 \mathrm{mg} \mathrm{g}^{-1}\right)$ variety and the lowest in the EV-1098 variety (Table 2, Fig. 1).

As for the roots $(\mathrm{R})$, the Cd uptake was significantly affected by the varieties $(\mathrm{V}), \mathrm{Cd}$ treatments $(\mathrm{T})$ and interaction between variety $(\mathrm{V}) \times$ treatments $(\mathrm{T})($ Table 2$)$. In the comparison between the Cd levels (Table 2), the highest uptake of $\mathrm{Cd}$ was recorded with $1000 \mu \mathrm{M} \mathrm{CdCl}_{2}\left(0.22 \mathrm{mg} \mathrm{g}^{-1}\right)$ followed by $500 \mu \mathrm{M} \mathrm{CdCl}_{2}\left(0.15 \mathrm{mg} \mathrm{g}^{-1}\right)$ with significant differences. In the case of varieties (Table 2), the higher Cd absorption in the roots of EV-6098 and Sadaf varieties with the values $0.16 \mathrm{mg} \mathrm{g}^{-1}$ and $0.14 \mathrm{mg} \mathrm{g}^{-1}$, respectively. The significant lower Cd uptake was found in the EV-1098 (0.10 $\left.\mathrm{mg} \mathrm{g}^{-1}\right)$ variety (Table 2, Fig. 1). The mean values (mean \pm standard error) for Cd uptake in the different plant parts and whole plant by all the studied varieties were shown in Fig. 1 . The highest amount of $\mathrm{Cd}$ for the whole plant was uptake by two varieties: SA-2002 and EV-6098. The lowest Cd was uptake by the EV-1098 variety (Fig. 1). 
Table 2. The concentration of $C d$ in crown tissue (Cd-CT), leaves $(C d-L)$ and roots $(C d-R)$; Ca concentration in crown tissue (Ca-CT), leaves $(C a-L)$, roots $(C a-R) ; K$ concentration in crown tissue $(K-C T)$, leaves $(K-L)$, roots $(K-R)$; and $P$ concentration in crown tissue $(P-C T)$, leaves $(P-L)$, roots $(P-R)$

\begin{tabular}{|c|c|c|c|c|c|c|c|c|c|c|c|c|c|}
\hline Traits & & Cd-CT & Cd-L & Cd-R & Ca-CT & Ca-L & Ca-R & K-CT & K-L & K-R & P-CT & P-L & P-R \\
\hline \multirow{6}{*}{$\begin{array}{c}\text { Maize } \\
\text { varieties } \\
\text { (V) }\end{array}$} & EV-1098 & $0.03 \mathrm{~d}$ & $0.05 \mathrm{e}$ & $0.10 \mathrm{~d}$ & $4.12 \mathrm{a}$ & $4.40 \mathrm{~b}$ & $4.53 \mathrm{~b}$ & $8.05 \mathrm{a}$ & $9.17 \mathrm{a}$ & $10.85 \mathrm{a}$ & $0.25 \mathrm{a}$ & $0.27 \mathrm{a}$ & $0.23 \mathrm{a}$ \\
\hline & SA-2002 & $0.10 \mathrm{a}$ & $0.12 \mathrm{a}$ & $0.13 \mathrm{c}$ & $3.55 \mathrm{~b}$ & $3.70 \mathrm{c}$ & $3.77 \mathrm{c}$ & $3.73 \mathrm{~d}$ & $4.27 \mathrm{e}$ & $5.37 \mathrm{e}$ & $0.17 \mathrm{e}$ & $0.18 \mathrm{~d}$ & $0.16 \mathrm{~d}$ \\
\hline & EV-5098 & $0.07 \mathrm{~b}$ & $0.09 \mathrm{c}$ & $0.12 \mathrm{c}$ & $3.75 \mathrm{~b}$ & $4.48 \mathrm{ab}$ & $4.77 \mathrm{a}$ & $5.22 \mathrm{c}$ & $6.17 \mathrm{c}$ & $7.48 \mathrm{c}$ & $0.21 b c$ & $0.22 \mathrm{~b}$ & $0.21 \mathrm{~b}$ \\
\hline & AG-2002 & $0.04 \mathrm{c}$ & $0.08 \mathrm{~d}$ & $0.09 \mathrm{e}$ & $3.57 \mathrm{~b}$ & $4.61 \mathrm{a}$ & $4.67 \mathrm{ab}$ & $5.86 \mathrm{~b}$ & $7.21 \mathrm{~b}$ & $8.83 \mathrm{~b}$ & $0.22 \mathrm{~b}$ & $0.20 \mathrm{c}$ & $0.22 \mathrm{a}$ \\
\hline & EV-6098 & $0.10 \mathrm{a}$ & $0.12 b$ & $0.16 \mathrm{a}$ & $3.74 \mathrm{~b}$ & $4.33 \mathrm{~b}$ & $4.48 \mathrm{~b}$ & $5.00 \mathrm{c}$ & $5.38 \mathrm{~d}$ & $6.66 \mathrm{~d}$ & $0.19 \mathrm{~d}$ & $0.20 \mathrm{c}$ & $0.21 \mathrm{~b}$ \\
\hline & Sadaf & $0.04 \mathrm{c}$ & $0.09 \mathrm{c}$ & $0.14 \mathrm{~b}$ & $3.69 \mathrm{~b}$ & $3.76 \mathrm{c}$ & $3.89 \mathrm{c}$ & $3.27 \mathrm{e}$ & $5.02 \mathrm{~d}$ & $6.61 \mathrm{~d}$ & $0.21 \mathrm{c}$ & $0.19 \mathrm{~cd}$ & $0.19 \mathrm{c}$ \\
\hline \multirow{3}{*}{$\begin{array}{c}\text { Treatments } \\
\text { (T) }\end{array}$} & To (Control) & $0.00 \mathrm{c}$ & $0.00 \mathrm{c}$ & $0.00 \mathrm{c}$ & $4.10 \mathrm{a}$ & $4.52 \mathrm{a}$ & $4.68 \mathrm{a}$ & $6.58 \mathrm{a}$ & $7.87 \mathrm{a}$ & $9.52 \mathrm{a}$ & $0.22 \mathrm{a}$ & $0.23 \mathrm{a}$ & $0.22 \mathrm{a}$ \\
\hline & $\mathrm{T} 1(500 \mu \mathrm{M})$ & $0.07 \mathrm{~b}$ & $0.11 \mathrm{~b}$ & $0.15 \mathrm{~b}$ & $3.74 \mathrm{~b}$ & $4.24 \mathrm{~b}$ & $4.34 \mathrm{~b}$ & $5.25 \mathrm{~b}$ & $6.01 \mathrm{~b}$ & $7.47 \mathrm{~b}$ & $0.21 \mathrm{~b}$ & $0.21 \mathrm{~b}$ & $0.21 \mathrm{~b}$ \\
\hline & $\mathrm{T} 2(1000 \mu \mathrm{M})$ & $0.12 \mathrm{a}$ & $0.17 \mathrm{a}$ & $0.22 \mathrm{a}$ & $3.37 \mathrm{c}$ & $3.88 \mathrm{c}$ & $4.03 \mathrm{c}$ & $3.74 \mathrm{~b}$ & $4.73 \mathrm{c}$ & $5.92 \mathrm{c}$ & $0.19 \mathrm{c}$ & $0.19 \mathrm{c}$ & $0.19 \mathrm{c}$ \\
\hline \multirow{3}{*}{ ANOVA } & $\mathrm{V}$ & $* * *$ & $* * *$ & $* * *$ & $* * *$ & $* * *$ & $* * *$ & $* * *$ & $* * *$ & $* * *$ & $* * *$ & $* * *$ & $* * *$ \\
\hline & $\mathrm{T}$ & $* * *$ & $* * *$ & $* * *$ & $* * *$ & $* * *$ & $* * *$ & $* * *$ & $* * *$ & $* * *$ & $* * *$ & $* * *$ & $* * *$ \\
\hline & $\mathrm{V} \times \mathrm{T}$ & $* * *$ & $* * *$ & $* * *$ & $* *$ & $* *$ & $* *$ & $* * *$ & $* * *$ & $* * *$ & ns & ns & ns \\
\hline
\end{tabular}

Means sharing different letters in the same column indicate the significant differences compared with Cd treatments and maize varieties according to Tukey's test $(p<0.05)$ 
The $\mathrm{Cd}, \mathrm{Ca}, \mathrm{K}$ and $\mathrm{P}$ contents in the different plant tissues (such as crown tissues, leaves and roots) were significantly affected by varieties, Cd levels and interaction between them (Table 2; Figs. 1,2). The maximum $\mathrm{Cd}$ was accumulated in the roots and minimum in the crown tissues of all varieties (Fig. S4). Additionally, the roots retained maximum $\mathrm{Cd}$ rather than crown tissues and leaves. In general, the EV-1098 variety showed a minimum uptake of $\mathrm{Cd}$ compared with other varieties (Fig. 1). However, the same variety performed better in terms of $\mathrm{Ca}, \mathrm{K}$ and $\mathrm{P}$ contents in different plant tissues as compared with other varieties (Fig. 2). In short, $\mathrm{Cd}$ contents in all plant tissues tended to increase with increased Cd level.

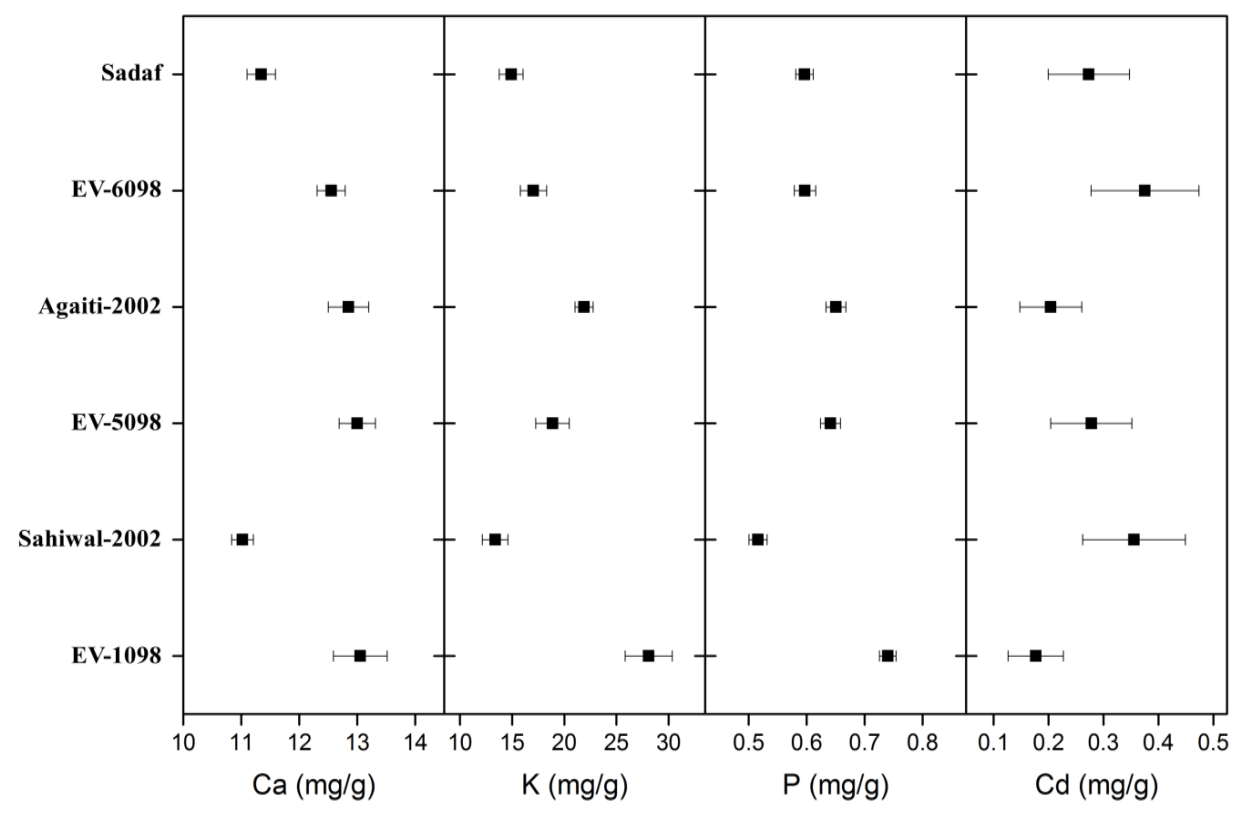

Figure 2. The concentration of $C a, K, P$ and $C d$ (mean $\pm S E)$ in the six maize varieties

The $\mathrm{Ca}, \mathrm{K}$ and $\mathrm{P}$ contents interacted and significantly changed with the increasing $\mathrm{Cd}$ treatments (Table 2). In control conditions, the varietal effect of $\mathrm{Ca}, \mathrm{K}$ and $\mathrm{P}$ contents were observed different significantly. However, an opposite trend was followed by $\mathrm{Ca}$, $\mathrm{K}$ and $\mathrm{P}$ contents in all plant parts under $\mathrm{Cd}$ treatments i.e. an increase in the $\mathrm{Cd}$ level resulted in a decrease in maize plant biochemical traits $(\mathrm{Ca}, \mathrm{K}$ and $\mathrm{P}$ contents) in the crown tissues, leaves and roots (Table 2).

The reduction in the plant total $\mathrm{Ca}, \mathrm{K}$ and $\mathrm{P}$ contents from the control level were recorded $85 \%, 60 \%$ and $85 \%$, respectively. All the varieties and treatments were found highly significant for the $\mathrm{Cd}, \mathrm{Ca}, \mathrm{K}$ and $\mathrm{P}$ contents in all plant parts (CT, L and $\mathrm{R}$ ), while variety $(\mathrm{V}) \times$ treatment $(\mathrm{T})$ interactions were recorded non-significant only for the $\mathrm{P}$ contents in all plant parts (Table 2). The $\mathrm{Ca}, \mathrm{K}$ and $\mathrm{P}$ contents exhibited significant positive correlations in three different plant parts (Fig. S5).

\section{Correlations between Cd, plant morphological and biochemical traits}

The regression lines were drawn to determine the correlation among different studied traits, such as plant total dry weight; and total Ca, K and P (Fig. 3). Results revealed that there existed a significantly positive correlation among plant total dry weight (PTDW); and total Ca (PT-Ca), K (PT-K) and P (PT-P). The linear regression 
coefficient reached to significant level for total $\mathrm{Ca}, \mathrm{K}$ and $\mathrm{P}$, respectively (Fig. 3). However, a significant negative correlation was observed among plant total Cd (PTCd), PT-Ca, PT-K and PT-P, total plant dry (PTDW) and fresh weight (PTFW) and plant height as shown in Fig. 3. The negative significant linear regression coefficient was recorded for total $\mathrm{Ca}, \mathrm{K}, \mathrm{P}$, total dry weight, total fresh weight and plant height (Fig. 3).
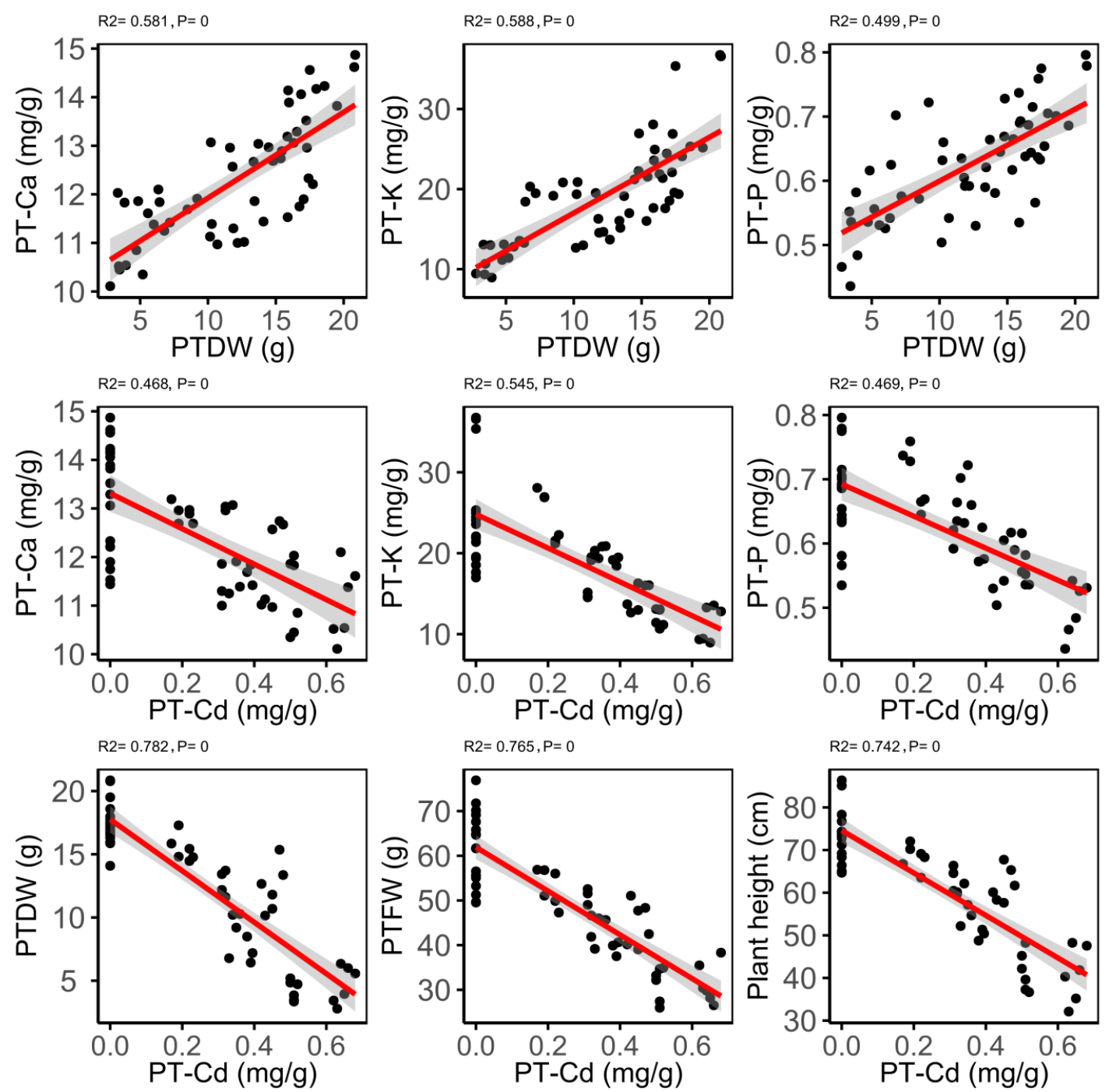

Figure 3. The relationship between plant total dry weight (PTDW) and total $C a, K$ and $P$ contents (PT-Ca, PT-K and PT- $P$, respectively) (in panel $a, b, c)$; plant total $C d(P T-C d)$ and total $\mathrm{Ca}, \mathrm{K}$ and $P$ contents (PT-Ca, PT-K and PT-P, respectively) (in panel $d, e, f)$; and plant total $C d(P T-C d)$ and total plant dry weight (PTDW), fresh weight (PTFW) and plant height (in panel $g, h, i)$

\section{Pearson correlation and principal component analysis (PCA)}

Pearson correlation for plant different traits was shown in Table 3. The different significant correlations (both positive and negative) were found among maize plant growth traits (shoot fresh weight (SFW), root fresh weight (RFW), shoot dry weight (SDW), root dry weight (RDW), shoot length (SL), root length (RL), stem diameter 
(SD) and the number of leaves per plant (NOL); biochemical traits (Ca concentration in crown tissue $(\mathrm{Ca}-\mathrm{CT})$, leaves $(\mathrm{Ca}-\mathrm{L})$, roots $(\mathrm{Ca}-\mathrm{R}), \mathrm{K}$ concentration in crown tissue $(\mathrm{K}$ $\mathrm{CT})$, leaves (K-L), roots (K-R), P concentration in crown tissue (P-CT), leaves (P-L), roots (P-R); and $\mathrm{Cd}$ related traits, such as $\mathrm{Cd}$ concentration in crown tissue (Cd-CT), leaves (Cd-L) and roots (Cd-R) (Table 3). Particularly, the $\mathrm{Cd}$ in all the plant parts (CT, $\mathrm{L}$ and $\mathrm{R}$ ) showed significant negative correlations with all the growth and biochemical traits of plants. Conversely, all growth traits exhibited significant positive correlations with all the biochemical traits (Table 3).

The principal component analysis (PCA) for this study is shown in Fig. 4. The first two PCA components exhibited maximum variation $(84.1 \%)$ for all the parameters tested within the dataset. The PC1 and PC2 explained $74.6 \%$ and $9.5 \%$ variations, respectively. Moreover, the PC1 was positively loaded by the variables SDW, RFW, SDW, RDW, SL, RL, SD, NOL, CaCT, CaL, CaR, KCT, KL, KR, PCT, PL and PR; and PC2 was positively loaded by the variables CdCT, CdL and CdR. In comparison, a strong negative correlation was observed between the PC1 and PC2 parameters (Fig. 4).

Effect of Cd on the plant biomass and related growth traits, different factors/indices for Cd translocation, bioaccumulation, bioconcentration and tolerance

\section{Translocation factors $(T F)$}

The translocation factors (TF) was used to determine the plant's ability to translocate $\mathrm{Cd}$ from the lower part (roots) to the aerial parts (crown tissue and leaves) of the plant, which are the mean values of different $\mathrm{Cd}$ treatments and maize varieties shown in Table 4. The variations in $\mathrm{TF}_{\mathrm{CT}}$ and $\mathrm{TF}_{\mathrm{L}}$ showed accordingly with the different treatments and varieties. $\mathrm{TF}_{\mathrm{CT}}$ and $\mathrm{TF}_{\mathrm{L}}$ values observed at $1000 \mu \mathrm{M}(0.54$ and 0.76$)$ were similar and not statistically different from those measured at $500 \mu \mathrm{M}(0.51$ and 0.74$)$ (Table 4).

\section{Bioconcentration factors (BCF)}

For BCF, neither significant differences were noted among Cd treatments $(\mathrm{p}>0.05)$ and nor for the different maize varieties (Table 4). The BCF showed an inverse relationship with $\mathrm{Cd}$ treatments, therefore with the increasing $\mathrm{Cd}$ supply, the $\mathrm{BCF}$ decreased (Table 4).

\section{Bioaccumulation factors (BAF)}

Conversely, BAF indicates the plant's capacity to accumulate $\mathrm{Cd}$ in the aerial part (crown tissue and leaves) of the plant, concerning the concentration of $\mathrm{Cd}$ in the substrate/soil. The variations in $\mathrm{BAF}_{\mathrm{CT}}$ and $\mathrm{BAF}_{\mathrm{L}}$ showed accordingly in Table 4. Maximum $\mathrm{BAF}_{\mathrm{CT}}$ and $\mathrm{BAF}_{\mathrm{L}}$ measured at $500 \mu \mathrm{M}(1.29$ and 1.87$)$ and $1000 \mu \mathrm{M}(1.05$ and 1.49) were not statistically different (Table 4).

\section{Tolerance index (TI)}

The significant differences $(\mathrm{p}<0.05)$ for TI were found at different treatments (Control, $500 \mu \mathrm{M}$ and $1000 \mu \mathrm{M}$ ) with TI values 1.01 , 0.77 , and 0.33 , respectively (Table 4). While, no significant differences ( $\mathrm{p}>0.05$ ) were observed between the varieties (EV-1098, SA-2002, EV-5098, AG-2002, EV-6098 and Sadaf) with TI values $0.75,0.64,0.65,0.74,0.72$, and 0.66 , respectively. TI was decreased with the increasing Cd supply (Table 4). 
Table 3. Pearson correlation for plant growth traits, biochemical traits and Cd related traits (Cd concentration in different plant tissues)

\begin{tabular}{|c|c|c|c|c|c|c|c|c|c|c|c|c|c|c|c|c|c|c|c|c|}
\hline Traits & SFW & RFW & SDW & RDW & SL & RL & SD & NOL & CdCT & CdL & CdR & CaCT & CaL & CaR & KCT & KL & KR & PCT & PL & PR \\
\hline SFW & 1 & & & & & & & & & & & & & & & & & & & \\
\hline RFW & $0.818^{* *}$ & 1 & & & & & & & & & & & & & & & & & & \\
\hline SDW & $0.865^{* *}$ & $0.861^{* *}$ & 1 & & & & & & & & & & & & & & & & & \\
\hline RDW & $0.831^{* * *}$ & $0.823^{* * *}$ & $0.932^{* *}$ & 1 & & & & & & & & & & & & & & & & \\
\hline SL & $0.863^{* *}$ & $0.821^{* *}$ & $0.933^{* *}$ & $0.937^{* *}$ & 1 & & & & & & & & & & & & & & & \\
\hline RL & $0.867^{* *}$ & $0.841^{* *}$ & $0.930^{* *}$ & $0.925^{* *}$ & $0.937^{* *}$ & 1 & & & & & & & & & & & & & & \\
\hline SD & $0.877^{* *}$ & $0.884^{* * *}$ & $0.960^{* *}$ & $0.936^{* *}$ & $0.949^{* *}$ & $0.937^{* *}$ & 1 & & & & & & & & & & & & & \\
\hline NOL & $0.584^{* *}$ & $0.714^{* *}$ & $0.682^{* *}$ & $0.636^{* *}$ & $0.625^{* *}$ & $0.631^{* *}$ & $0.676^{* *}$ & 1 & & & & & & & & & & & & \\
\hline CdCT & $-0.804^{* *}$ & $-0.777^{* *}$ & $-0.822^{* * *}$ & $-0.797^{* *}$ & $-0.819^{* * *}$ & $-0.834^{* *}$ & $-0.837^{* *}$ & $-0.629^{* *}$ & 1 & & & & & & & & & & & \\
\hline CdL & $-0.832^{* * *}$ & $-0.828^{* *}$ & $-0.889^{* *}$ & $-0.852^{* *}$ & $-0.871^{* *}$ & $-0.887^{* * *}$ & $-0.906^{* * *}$ & $-0.712^{* *}$ & $0.959^{* *}$ & 1 & & & & & & & & & & \\
\hline CdR & $-0.811^{* * *}$ & $-0.840^{* * *}$ & $-0.873^{* *}$ & $-0.839^{* * *}$ & $-0.840^{* * *}$ & $-0.863^{* * *}$ & $-0.892^{* * *}$ & $-0.689^{* *}$ & $0.879^{* *}$ & $0.939^{* *}$ & 1 & & & & & & & & & \\
\hline $\mathrm{CaCT}$ & $0.748^{* *}$ & $0.740^{* * *}$ & $0.789^{* *}$ & $0.771^{* *}$ & $0.765^{* *}$ & $0.774^{* *}$ & $0.789^{* *}$ & $0.658^{* *}$ & $-0.670^{* * *}$ & $-0.760^{* *}$ & $-0.704^{* *}$ & 1 & & & & & & & & \\
\hline CaL & $0.592^{* *}$ & $0.462^{* *}$ & $0.651^{* *}$ & $0.649^{* *}$ & $0.630^{* *}$ & $0.669^{* *}$ & $0.666^{* *}$ & 0.257 & $-0.510^{* * *}$ & $-0.574^{* * *}$ & $-0.590^{* *}$ & $0.551^{* *}$ & 1 & & & & & & & \\
\hline CaR & $0.572^{* *}$ & $0.397^{* *}$ & $0.600^{* *}$ & $0.602^{* *}$ & $0.570^{* *}$ & $0.625^{* *}$ & $0.619^{* *}$ & $0.285^{*}$ & $-0.486^{* *}$ & $-0.559^{* * *}$ & $-0.565^{* *}$ & $0.523^{* *}$ & $0.917^{* * *}$ & 1 & & & & & & \\
\hline KCT & $0.709^{* * *}$ & $0.629^{* *}$ & $0.725^{* *}$ & $0.749^{* *}$ & $0.709^{* *}$ & $0.734^{* *}$ & $0.741^{* *}$ & $0.472^{* *}$ & $-0.622^{* *}$ & $-0.670^{* *}$ & $-0.668^{* *}$ & $0.718^{* *}$ & $0.781^{* * *}$ & $0.756^{* *}$ & 1 & & & & & \\
\hline $\mathbf{K L}$ & $0.780^{* * *}$ & $0.683^{* *}$ & $0.750^{* *}$ & $0.749^{* *}$ & $0.749^{* *}$ & $0.783^{* *}$ & $0.776^{* *}$ & $0.518^{* *}$ & $-0.751^{* *}$ & $-0.755^{* *}$ & $-0.719^{* *}$ & $0.731^{* *}$ & $0.769^{* *}$ & $0.737^{* *}$ & $0.945^{* *}$ & 1 & & & & \\
\hline KR & $0.787^{* * *}$ & $0.712^{* *}$ & $0.752^{* *}$ & $0.761^{* *}$ & $0.756^{* *}$ & $0.781^{* *}$ & $0.792^{* *}$ & $0.520^{* *}$ & $-0.750^{* *}$ & $-0.759^{* *}$ & $-0.714^{* *}$ & $0.735^{* *}$ & $0.771^{* * *}$ & $0.735^{* *}$ & $0.923^{* * *}$ & $0.983^{* *}$ & 1 & & & \\
\hline PCT & $0.719^{* * *}$ & $0.613^{* *}$ & $0.686^{* *}$ & $0.680^{* * *}$ & $0.692^{* *}$ & $0.708^{* *}$ & $0.713^{* *}$ & $0.404^{* *}$ & $-0.745^{* *}$ & $-0.710^{* *}$ & $-0.587^{* *}$ & $0.661^{* *}$ & $0.679^{* * *}$ & $0.642^{* *}$ & $0.784^{* *}$ & $0.871^{* *}$ & $0.884^{* *}$ & 1 & & \\
\hline PL & $0.610^{* *}$ & $0.499^{* * *}$ & $0.589^{* *}$ & $0.611^{* *}$ & $0.613^{* *}$ & $0.611^{* *}$ & $0.616^{* *}$ & $0.440^{* *}$ & $-0.615^{* * *}$ & $-0.643^{* *}$ & $-0.534^{* *}$ & $0.744^{* *}$ & $0.583^{* * *}$ & $0.572^{* *}$ & $0.832^{* *}$ & $0.852^{* *}$ & $0.841^{* * *}$ & $0.829^{\text {*** }}$ & 1 & \\
\hline PR & $0.676^{* *}$ & $0.579^{* *}$ & $0.700^{* *}$ & $0.711^{* * *}$ & $0.701^{* *}$ & $0.729^{* *}$ & $0.724^{* *}$ & $0.319^{*}$ & $-0.671^{* * *}$ & $-0.683^{* *}$ & $-0.602^{* *}$ & $0.660^{* *}$ & $0.838^{* * *}$ & $0.801^{* *}$ & $0.812^{* * *}$ & $0.838^{* * *}$ & $0.848^{* *}$ & $0.892^{* *}$ & $0.742^{* * *}$ & 1 \\
\hline
\end{tabular}

SFW: shoot fresh weight; RFW: root fresh weight; SDW: shoot dry weight; RDW: root dry weight; SL: shoot length; RL: root length; SD: stem diameter; NOL: number of leaves; CdCT: Cd concentration in crown tissue; CdL: Cd concentration in leaves; CdR: Cd concentration in roots; CaCT: Ca concentration in crown tissue; $\mathrm{CaL}$ : Ca concentration in leaves; CaR: Ca concentration in roots; $\mathrm{KCT}$ : $\mathrm{K}$ concentration in crown tissue; KL: K concentration in leaves; KR: $\mathrm{K}$ concentration in roots; PCT: P concentration in crown tissue; PL: $\mathrm{P}$ concentration in leaves; PR: $\mathrm{P}$ concentration in roots. Correlation is significant at $* * p \leq 0.01$ and $* p \leq 0.05$ 


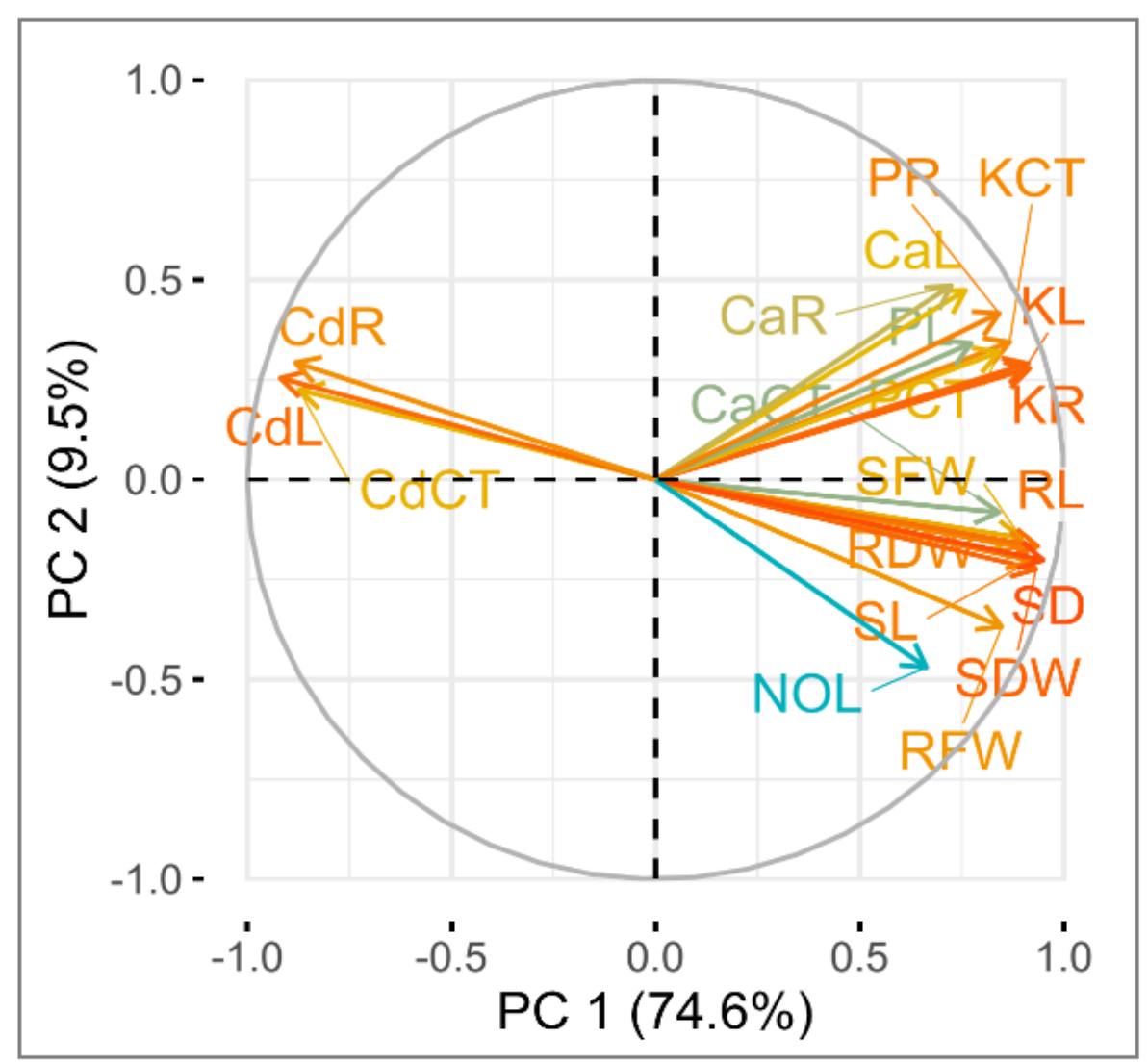

Figure 4. The expression of growth traits, biochemical traits and Cd (in the different plant parts) on the two principal components analysis (PCA) axes. Loading values for PC axis 1 and 2; and color's difference show the contribution of each trait/variable

Table 4. Bioaccumulation factor (BAF), bioconcentration factor $(B C F)$, translocation factor $(T F)$ and tolerance index (TI) values for cadmium in the crown tissue $(C T)$, leaves $(L)$ and roots $(R)$ according to different $C d$ treatments and maize varieties

\begin{tabular}{|c|c|c|c|c|c|c|c|}
\hline \multirow{2}{*}{ Factors } & & \multicolumn{2}{|c|}{ BAF } & \multirow{2}{*}{ BCF } & \multicolumn{2}{|c|}{$\mathbf{T F}$} & \multirow{2}{*}{ TI } \\
\hline & & BAFCT & $\mathbf{B A F}_{\mathbf{L}}$ & & TF $_{\text {CT }}$ & $\mathbf{T F}_{\mathbf{L}}$ & \\
\hline \multirow{3}{*}{$\begin{array}{c}\text { Treatments } \\
\text { (T) }\end{array}$} & To (Control) & 0.00 & 0.00 & 0.00 & 0.00 & 0.00 & $1.01 \mathrm{a}$ \\
\hline & $\mathrm{T} 1(500 \mu \mathrm{M})$ & 1.29 & 1.87 & 2.60 & 0.51 & 0.74 & $0.77 b$ \\
\hline & $\mathrm{T} 2(1000 \mu \mathrm{M})$ & 1.05 & 1.49 & 1.97 & 0.54 & 0.76 & $0.33 \mathrm{c}$ \\
\hline \multirow{6}{*}{$\begin{array}{c}\text { Maize } \\
\text { varieties } \\
\text { (V) }\end{array}$} & EV-1098 & 0.35 & 0.58 & 1.19 & 0.20 & 0.33 & 0.75 \\
\hline & SA-2002 & 1.26 & 1.54 & 1.65 & 0.52 & 0.64 & 0.64 \\
\hline & EV-5098 & 0.83 & 1.13 & 1.48 & 0.37 & 0.50 & 0.65 \\
\hline & AG-2002 & 0.50 & 0.95 & 1.02 & 0.33 & 0.62 & 0.74 \\
\hline & EV-6098 & 1.26 & 1.47 & 2.00 & 0.42 & 0.49 & 0.72 \\
\hline & & 0.50 & 1.04 & 1.81 & 0.19 & 0.39 & 0.66 \\
\hline
\end{tabular}

Different letters in the same column indicate the significant differences compared with $\mathrm{Cd}$ treatments and maize varieties according to Tukey's test $(p<0.05)$ 


\section{Discussion}

\section{Effect of Cd on the plant biomass and related growth traits}

The growth traits such as SFW, RFW, SDW, RDW, SL, RL, SD and NOL interacted and significantly changed with the $\mathrm{Cd}$ treatments (Table 1). The growth traits of all varieties were reduced at applied $\mathrm{Cd}$ treatments and the highest reduction in these traits was pragmatic at $1000 \mu \mathrm{M} \mathrm{CdCl}_{2}$ treatment level (Table 1). The growth traits decreased with the increasing Cd supply in the substrate/soil (Rascio et al., 1993; Klaus et al., 2013; Alia et al., 2015; Anjum et al., 2015). The fresh and dry weights of shoot and root; and shoot and root length reduced with increasing Cd level (Table 1). This reduction in the fresh and dry biomass as well as the length of maize plants may be due to Cd toxicity as well as nutrient disparity, lower water rate and nutrient uptake in plants (Ghani, 2010; Faizan et al., 2011; Alia et al., 2015; Rizwan et al., 2017; Abedi and Mojiri, 2020). Moreover, this could be due to a reduction in xylem transport caused by the interruption of the transpiration process in metal hassle, especially Cd (Hayat et al., 2020). The Cd toxicity also decreased the SD and NOL of maize plants i.e. the decreased trend with the exceeding Cd supply was observed (Table 1) in previous studies (Aslam et al., 2015; Figlioli et al., 2019). Generally speaking, the EV-1098 and AG-2002 variety performed better for all the growth traits than other varieties. However, the growth traits showed a significant decreasing trend for all the six varieties with an increased level of Cd (Table 1).

\section{Cd uptake, translocation, partitioning and its effect on the different biochemical traits}

The Cd uptake, translocation, partitioning and its effect on the different biochemical traits were observed in the different plant parts (leaves, crown tissue, and roots) of all varieties of maize at different Cd levels (Table 2). The $\mathrm{Cd}$ partitioning in the crown tissue, leaves and roots was substantially affected by the varieties, Cd levels and their interactions; particularly at higher $\mathrm{Cd}$ levels. The $\mathrm{Cd}$ accumulation gradually increased with increasing applied Cd levels in all the studied plant parts (Table 2), as observed in the former study (Nguyen et al., 2016). The Cd accumulation trend was recorded as: crown tissue < leaves < roots, $58 \%, 65 \%$ and $68 \%$, respectively. The maize extraction capacity exhibit that the maize has the potential to accumulate heavy metals especially $\mathrm{Cd}$ and can be used for phytoextraction purposes (Retamal-Salgado et al., 2017). The maximum $\mathrm{Cd}$ was accumulated in the roots of all the six maize varieties rather than aerial plant parts (Table 2), similar results were found in previos studies (Zhao, 2011; Stritsis and Claassen, 2013; Singh and Srivastava, 2016; Ling et al., 2017; BorosLajszner et al., 2020), these results are in contrast to that the maximum $\mathrm{Cd}$ was accumulated in the plant aerial parts of maize rather than roots (Retamal-Salgado et al., 2017). It may be due to that the root first comes into contact with $\mathrm{Cd}$ and due to its immobility, more Cd retained in the roots (Anjum et al., 2015). Moreover, the Cd translocation from roots to aerial plant parts also limited by the suberization of endoderm and lignification of root cortex cells (Kaznina and Titov, 2014). For varieties, the minimum Cd concentration was noted for the EV-1098 variety (Table 2, Fig. 1), this is because the higher dry mass production was recorded in the same variety (Table 1) than other varieties (Trejo et al., 2016; Retamal-Salgado et al., 2017). The limitations of $\mathrm{Cd}$ accumulation in the roots and translocation from roots to other plant parts and several other factors could be involved to deal with Cd toxicity in maize (Yang et al., 2014). It may suggest that maize has effective and strong defense mechanisms to reduce 
$\mathrm{Cd}$ toxic effect than all other crops, including the $\mathrm{Cd}$ accumulation in the roots (Retamal-Salgado et al., 2017). Secondly, the Zn availability in the soils plays an important antagonistic role for $\mathrm{Cd}$ accumulation in the maize plants (Rizwan et al., 2019). Finally, the lower Cd levels possibly attributed to the higher efficiency of growth traits (Table 1) and biochemical traits/nutrients (Table 2), which result in the dilution of Cd toxic effect on maize plant (Retamal-Salgado et al., 2017; Rizwan et al., 2019). Overall, the total Cd extraction is also found significantly higher in the roots than the crown tissue and leaves (Table 2) (Singh and Srivastava, 2016; Boros-Lajszner et al., 2020). The same pattern was found in the other plants like wheat (Abedi and Mojiri, 2020) and mustard and oats (Boros-Lajszner et al., 2020).

The micro- and macro, both types of nutrients are required to perform the normal functioning, growth, and development in the plants. The deficiency of these nutrients, especially of macronutrients such as potassium, phosphorus, or calcium significantly affects the plant's metabolic processes (Sitko et al., 2019). The process of photosynthesis can't occur without the nutrients supply and directly dependent on mineral nutrition in plants (Engels et al., 2012). The uptake of heavy metals occurs in competition with other metals/elements such as $\mathrm{Zn}, \mathrm{Cu}, \mathrm{Mn}, \mathrm{Cd}$ and $\mathrm{Fe}$ and may reduce the Fe, K, P, Zn and Ca uptake in the plants (Engels et al., 2012; Alia et al., 2015). The $\mathrm{Ca}, \mathrm{K}$ and $\mathrm{P}$ are among essential nutrients that are required for plant growth (Engels et al., 2012). The Cd uptake, accumulation and partitioning adversely affect the nutrients uptake and distribution in plants (Alia et al., 2015). The $\mathrm{Ca}, \mathrm{K}$ and $\mathrm{P}$ contents in the different plant tissues were significantly affected by varieties, $\mathrm{Cd}$ levels and interaction between them (Fig. 3, Table 2). In short, the $\mathrm{Ca}, \mathrm{K}$ and $\mathrm{P}$ contents interacted and significantly decreased with the increasing applied Cd levels in all the studied plant parts of all the six maize varieties (Table 2) (Alia et al., 2015; Nguyen et al., 2016). The higher $\mathrm{Cd}$ concentration interrupts the ATPase and other enzymes functioning which uptake the $\mathrm{K}$ and as a consequence reduced $\mathrm{K}$ availability for plants (Erel et al., 2015). The $\mathrm{K}$ deficiency indirectly influences the photosynthetic activity and stomatal conductance of plants (Akram et al., 2020). Thus, a sufficient amount of $\mathrm{K}$ contents is necessary for the higher rate of plant water contents, transpiration, and stomatal conductance (Jin et al., 2011; Sitko et al., 2019). Ca plays an active role in stress signals transduction and works as an intracellular messenger (Engels et al., 2012; Hochmal et al., 2015). The distribution and uptake of Ca also considerably reduced because of the Cd treatment (Table 2), which may be due to the disruption of essential nutrient uptake supply like K, Ca and $\mathrm{Zn}$ by $\mathrm{Cd}$ (Alia et al., 2015). Moreover, the increase in Cd concentration also decreased the phosphorus contents in all parts of the maize plant (Table 2) (Shareef et al., 2018). Phosphorus is one of the main macronutrients that are necessary for nucleic acids, membrane lipids and the synthesis of ATP in addition to other metabolites (Akram et al., 2020). Moreover, P deficiency can disturb the regulation of stomata and transpiration (Singh et al., 2017; Sitko et al., 2019). In varieties, the EV-1098 variety performed better in terms of $\mathrm{Ca}, \mathrm{K}$ and $\mathrm{P}$ contents in different plant parts and uptake maximum $\mathrm{Ca}, \mathrm{K}$ and $\mathrm{P}$ as compared with other varieties (Table 2, Fig. 2) because minimum Cd uptake was noted for the same variety (Table 2). It also supports that increasing $\mathrm{Cd}$ levels decrease the minerals uptake and vice versa (Table 2) (Alia et al., 2015; Nguyen et al., 2016). 


\section{Pearson correlation and principal component analysis (PCA)}

The positive correlations between growth traits (SFW, RFW, SDW, RDW, SL, RL, SD and NOL) with biochemical traits (CaCT, CaL, CaR, KCT, KL, KR, PCT, PL and PR) (Table 3) exhibit the contribution of biochemical traits in the growth and biomass production of maize varieties. The adverse effects of $\mathrm{Cd}$ on the plant growth and biochemical traits in all plant parts (Tables 1-3) may be attributed to the disruption of essential plant nutrients absorption pattern by decreasing the efficacy of root proliferation. Moreover, the distribution and uptake of $\mathrm{Cd}$ associated with metal transporters (divalent cations), as the nutrients uptake higher, may result in the form of direct conflict with $\mathrm{Cd}$ for transportation in the plants (Naveed et al., 2020). Further, all the $\mathrm{Cd}$ treatments and studied plant traits were effectively displaced along with the first two PC axes (Fig. 4), which suggests the applied Cd treatments had a deteriorative effect on the studied traits of maize plants to the control (Kaznina and Titov, 2014; Nguyen et al., 2016).

\section{Different factors/indices for Cd translocation, bioaccumulation, bioconcentration and tolerance}

The plant's phytoextraction capacity is defined as TF, which is the measure of $\mathrm{Cd}$ concentration in the aerial parts and the roots of the plant (Retamal-Salgado et al., 2017). For all the treatments, $\mathrm{TF}_{\mathrm{CT}}$ and $\mathrm{TF}_{\mathrm{L}}$ values were found <1 (Table 4), which meant that the $\mathrm{Cd}$ concentration in the roots was higher than other plant tissues (crown tissue and leaves). As for 0 and $1000 \mu \mathrm{M}$, the big difference between the concentrations of roots and other plant parts suggests that there is an internal restriction for the $\mathrm{Cd}$ transport from roots to other plant tissues, resulting in higher $\mathrm{Cd}$ concentrations in roots rather than crown tissue and leaves (Table 2). The apoplastic barriers in the roots of maize played a significant role under Cd stress. Higher $\mathrm{Cd}$ concentrations may result in harm to root apoplastic barriers, which would be helpful in retarding $\mathrm{Cd}$ ion's transport from roots to other plant tissues (Ling et al., 2017). The TF values in this study (Table 4 ) don't coincide with the findings of the earlier researchers and TF values found lower than the reported values (Liu et al., 2013; Azzi et al., 2017; Retamal-Salgado et al., 2017), which may be affected by soil $\mathrm{pH}$ and differences of Cd treatment that result in the reduction of Cd supply from roots to the plant aerial parts (Liu et al., 2013). This result indicates the low $\mathrm{Cd}$ translocation efficiency of maize varieties used in this study.

The $\mathrm{Cd}$ absorption capacity of plants from substrate/soil is defined as BCF, which is the relationship of $\mathrm{Cd}$ concentration in the plant roots and the substrate/soil. The $\mathrm{BCF}$ values vary from 1.02 to 2.60 (Table 4) and found higher than the results of other authors (Retamal-Salgado et al., 2017), which may be due to difference in the Cd treatments and maize cultivars/varieties response to Cd stress (Ghani, 2010; Nguyen et al., 2016; Shah et al., 2016; Rizwan et al., 2017). The BCF values >1 (Table 4) exhibit the high Cd bioaccumulation capacity of maize at the root level (Table 2) (Singh and Srivastava, 2016). However, most of the BAF values found comparatively lower than $\mathrm{BCF}$ values (Table 4). It is an indication of an intrinsic limitation on $\mathrm{Cd}$ transport from roots to the aerial parts (crown tissue and leaves), resulting in higher Cd concentrations retains in the roots rather than other plant parts (Table 2) (Ling et al., 2017). Consequently, high $\mathrm{Cd}$ concentration interrupts the apoplastic pathway and retard the Cd transport from roots to aerial parts (Ling et al., 2017; Retamal-Salgado et al., 2017). 
The dry mass production in the different parts (crown tissue, leaves and roots) of maize plants were impaired by the different Cd levels (Tables 1, 4); whereas no significant differences were noted between the varieties for TI values (Table 4). It may be due to the higher $\mathrm{Cd}$ concentration that damaged the plant roots, affect nutrients uptake in the roots and subsequently reduce/inhibit the plant growth (Klaus et al., 2013; Kaznina and Titov, 2014; Yang et al., 2014). The Cd levels (Yang et al., 2014) were lower than those used in this study, it suggests that Cd levels applied in substrate/soil are higher than the threat threshold $\left(3.5 \mathrm{mg} \mathrm{kg}^{-1}\right.$ ) (Yang et al., 2014). The decreased TI value with the increasing Cd supply (Table 4) further strengthens that the high $\mathrm{Cd}$ concentrations reduce the plant growth (Ghani, 2010).

\section{Conclusions}

The growth (plant biomass, height, stem diameter and the number of leaves) and biochemical traits $(\mathrm{Ca}, \mathrm{K}$ and $\mathrm{P}$ ) are found sensitive to $\mathrm{Cd}$ stress and negatively influenced by different $\mathrm{Cd}$ levels. The $\mathrm{Cd}$ toxic effect directly depended on the applied $\mathrm{Cd}$ stress, an increase in the $\mathrm{Cd}$ level resulted in a decrease in maize plant growth and biochemical traits. A considerable positive correlation was noted between the growth and biochemical traits. The uptake, translocation and partitioning of $\mathrm{Cd}$ were varied between the different plant parts and varieties, while, the $\mathrm{Cd}$ contents in all plant parts tended to increase with increased $\mathrm{Cd}$ level. The translocation factor $(\mathrm{TF}<1)$ values emphasize that maize roots have some internal restriction, so the low $\mathrm{Cd}$ is translocated from the substrate to roots. Moreover, the maximum $\mathrm{Cd}$ accumulated and retained in the roots rather than crown tissues and leaves of studied maize varieties. The EV-1098 variety performed better for all growth and biochemical traits than other varieties. Further, the EV-1098 variety was found tolerant to Cd stress even at higher Cd levels $(1000 \mu \mathrm{M})$; while SA-2002 and EV-6098 sensitive. The results revealed the diverse varietal performance/response of studied maize varieties to induced $\mathrm{Cd}$ toxicity. Consequently, the EV-1098 variety could be good in terms of the growth in Cd-polluted soils. In future, molecular studies are suggested at gene level to better understand the $\mathrm{Cd}$ interaction with the plant's physiological and metabolic processes.

Acknowledgements. This study was supported by grants from the Innovation Base Project of Gansu Province (20190323), the National Natural Science Foundation of China (31770430, 31322010, 31270753 and 31700463), the National Youth Top-notch Talent Support Program to JMD, and Fundamental Research Funds for Central Universities (lzujbky-2018-ct06, lzujbky-2016-k03/218, lzujbky-2015-84).

\section{REFERENCES}

[1] Abdu, N., Abdullahi, A. A., Abdulkadir, A. (2017): Heavy metals and soil microbes. Environmental chemistry letters 15: 65-84.

[2] Abedi, T., Mojiri, A. (2020): Cadmium uptake by wheat (Triticum aestivum L.): An overview. - Plants 9: 500.

[3] Akhter, M. F., Omelon, C. R., Gordon, R. A., Moser, D., Macfie, S. M. (2014): Localization and chemical speciation of cadmium in the roots of barley and lettuce. Environmental and Experimental Botany 100: 10-19. 
[4] Akram, M. A., Iqbal, N., Aqeel, M., Khalid, N., Alamri, S., Hashem, M., Abrar, M., Manan, A., Islam, W., Noman, A. (2020): Exploration of medicinal phyto-diversity of the semi-arid area in Punjab province, Pakistan. - The J. Anim. Plant Sci. 30: 1442-1464.

[5] Akram, M. A., Wang, X., Hu, W., Xiong, J., Zhang, Y., Deng, Y., Ran, J., Deng, J. (2020): Convergent variations in the leaf traits of desert plants. - Plants 9: 990.

[6] Ali, S., Liu, Y., Ishaq, M., Shah, T., Ilyas, A., Din, I. U. (2017): Climate change and its impact on the yield of major food crops: Evidence from Pakistan. - Foods 6: 39.

[7] Ali, S., Abbas, Z., Rizwan, M., Zaheer, I. E., Yavaş, İ., Ünay, A., Abdel-Daim, M. M., Bin-Jumah, M., Hasanuzzaman, M., Kalderis, D. (2020): Application of floating aquatic plants in phytoremediation of heavy metals polluted water: A review. - Sustainability 12: 1927.

[8] Alia, N., Sardar, K., Said, M., Salma, K., Sadia, A., Sadaf, S., Toqeer, A., Miklas, S. (2015): Toxicity and bioaccumulation of heavy metals in spinach (Spinacia oleracea) grown in a controlled environment. - International journal of environmental research and public health 12: 7400-7416.

[9] Amin, N., Ayaz, M., Alam, S., Gul, S. (2014): Heavy metals contamination through industrial effluent to irrigation water in Gadoon amazai (Swabi) and Hayatabad (Peshawar) Pakistan. - Journal of Scientific Research 6: 111-124.

[10] Anjum, S. A., Tanveer, M., Hussain, S., Bao, M., Wang, L., Khan, I., Ullah, E., Tung, S. A., Samad, R. A., Shahzad, B. (2015): Cadmium toxicity in maize (zea mays 1.): Consequences on antioxidative systems, reactive oxygen species and cadmium accumulation. - Environmental Science and Pollution Research 22: 17022-17030.

[11] Aslam, M., Zamir, M., Anjum, S., Khan, I., Tanveer, M. (2015): An investigation into morphological and physiological approaches to screen maize (Zea mays L.) hybrids for drought tolerance. - Cereal Research Communications 43: 41-51.

[12] Azzi, V., Kanso, A., Kazpard, V., Kobeissi, A., Lartiges, B., El Samrani, A. (2017): Lactuca sativa growth in compacted and non-compacted semi-arid alkaline soil under phosphate fertilizer treatment and cadmium contamination. - Soil and tillage research 165: $1-10$.

[13] Bashir, M. K., Schilizzi, S., Pandit, R. (2012): The determinants of rural household food security for landless households of the Punjab, Pakistan. - Working paper 1208, School of Agricultural and Resource Economics, The University of Western Australia.

[14] Boros-Lajszner, E., Wyszkowska, J., Kucharski, J. (2020): Application of white mustard and oats in the phytostabilisation of soil contaminated with cadmium with the addition of cellulose and urea. - Journal of Soils and Sediments 20: 931-942.

[15] Coakley, S., Cahill, G., Enright, A.-M., O'Rourke, B., Petti, C. (2019): Cadmium hyperaccumulation and translocation in impatiens glandulifera: From foe to friend? Sustainability 11: 5018.

[16] Engels, C., Kirkby, E., White, P. (2012): Mineral nutrition, yield and source-sink relationships. - Marschner's mineral nutrition of higher plants, pp. 85-133.

[17] Erel, R., Yermiyahu, U., Ben-Gal, A., Dag, A., Shapira, O., Schwartz, A. (2015): Modification of non-stomatal limitation and photoprotection due to $\mathrm{K}$ and Na nutrition of olive trees. - Journal of plant physiology 177: 1-10.

[18] Fahad, S., Hussain, S., Khan, F., Wu, C., Saud, S., Hassan, S., Ahmad, N., Gang, D., Ullah, A., Huang, J. (2015): Effects of tire rubber ash and zinc sulfate on crop productivity and cadmium accumulation in five rice cultivars under field conditions. Environmental Science and Pollution Research 22: 12424-12434.

[19] Faizan, S., Kausar, S., Perveen, R. (2011): Varietal differences for cadmium-induced seedling mortality, foliar toxicity symptoms, plant growth, proline and nitrate reductase activity in chickpea (Cicer arietinum L.). - Biol Med 3: 196-206.

[20] Figlioli, F., Sorrentino, M. C., Memoli, V., Arena, C., Maisto, G., Giordano, S., Capozzi, F., Spagnuolo, V. (2019): Overall plant responses to cd and pb metal stress in maize: 
Growth pattern, ultrastructure, and photosynthetic activity. - Environmental Science and Pollution Research 26: 1781-1790.

[21] Ghani, A. (2010): Effect of cadmium toxicity on the growth and yield components of mungbean [Vigna radiata (L.) Wilczek]. - World Appl Sci J 8: 26-29.

[22] Godinho, D. P., Serrano, H. C., Da Silva, A. B., Branquinho, C., Magalhães, S. (2018): Effect of cadmium accumulation on the performance of plants and of herbivores that cope differently with organic defenses. - Frontiers in plant science 9: 1723.

[23] Hayat, F., Ahmed, M. A., Zarebanadkouki, M., Javaux, M., Cai, G., Carminati, A. (2020): Transpiration reduction in maize (Zea mays L.) in response to soil drying. Frontiers in Plant Science 10: 1695.

[24] Henson, T. M., Cory, W., Rutter, M. T. (2013): Extensive variation in cadmium tolerance and accumulation among populations of Chamaecrista fasciculata. - PloS one 8: e63200.

[25] Hoagland, D. R., Arnon, D. I. (1950): The water-culture method for growing plants without soil. - Circular. California agricultural experiment station 347.

[26] Hochmal, A. K., Schulze, S., Trompelt, K., Hippler, M. (2015): Calcium-dependent regulation of photosynthesis. - Biochimica et Biophysica Acta (BBA)-Bioenergetics 1847: 993-1003.

[27] Huang, R., Dong, M., Mao, P., Zhuang, P., Paz-Ferreiro, J., Li, Y., Li, Y., Hu, X., Netherway, P., Li, Z. (2020): Evaluation of phytoremediation potential of five cd (hyper) accumulators in two cd contaminated soils. - Science of The Total Environment: 137581.

[28] Ismael, M. A., Elyamine, A. M., Moussa, M. G., Cai, M., Zhao, X., Hu, C. (2019): Cadmium in plants: Uptake, toxicity, and its interactions with selenium fertilizers. Metallomics 11: 255-277.

[29] Jin, S. H., Huang, J. Q., Li, X. Q., Zheng, B. S., Wu, J. S., Wang, Z. J., Liu, G. H., Chen, M. (2011): Effects of potassium supply on limitations of photosynthesis by mesophyll diffusion conductance in Carya cathayensis. - Tree physiology 31: 1142-1151.

[30] Kaznina, N., Titov, A. (2014): The influence of cadmium on physiological processes and productivity of poaceae plants. - Biology Bulletin Reviews 4: 335-348.

[31] Klaus, A., Lysenko, E., Kholodova, V. (2013): Maize plant growth and accumulation of photosynthetic pigments at short-and long-term exposure to cadmium. - Russian journal of plant physiology 60: 250-259.

[32] Liao, Z., Chen, Y., Ma, J., Islam, M., Weng, L., Li, Y. (2019): Cd, cu, and Zn accumulations caused by long-term fertilization in greenhouse soils and their potential risk assessment. - International journal of environmental research and public health 16 : 2805.

[33] Ling, T., Gao, Q., Du, H., Zhao, Q., Ren, J. (2017): Growing, physiological responses and cd uptake of corn (Zea mays L.) under different Cd supply. - Chemical Speciation \& Bioavailability 29: 216-221.

[34] Liu, Y., Hou, P., Xie, R., Li, S., Zhang, H., Ming, B., Ma, D., Liang, S. (2013): Spatial adaptabilities of spring maize to variation of climatic conditions. - Crop Science 53: 1693-1703.

[35] Mahmood, A., Malik, R. N. (2014): Human health risk assessment of heavy metals via consumption of contaminated vegetables collected from different irrigation sources in Lahore, Pakistan. - Arabian Journal of Chemistry 7: 91-99.

[36] Marquez, J. E., Pourret, O., Faucon, M.-P., Weber, S., Hoang, T. B. H., Martinez, R. E. (2018): Effect of cadmium, copper and lead on the growth of rice in the coal mining region of Quang ninh, Cam-pha (Vietnam). - Sustainability 10: 1758.

[37] Najam, S., Nawaz, R., Ahmad, S., Ehsan, N., Khan, M., Nawaz, M. (2015): Heavy metals contamination of soils and vegetables irrigated with municipal wastewater: A case study of Faisalabad, Pakistan. - J. Environ. Agric. Sci 4: 6-10.

[38] Naveed, M., Mustafa, A., Majeed, S., Naseem, Z., Saeed, Q., Khan, A., Nawaz, A., Baig, K. S., Chen, J.-T. (2020): Enhancing cadmium tolerance and pea plant health through Enterobacter sp. Mn17 inoculation together with biochar and gravel sand. - Plants 9: 530. 
[39] Nguyen, C., Soulier, A.-J., Masson, P., Bussiere, S., Cornu, J.-Y. (2016): Accumulation of $\mathrm{Cd}, \mathrm{Cu}$ and $\mathrm{Zn}$ in shoots of maize (Zea mays L.) exposed to 0.8 or $20 \mathrm{~nm} \mathrm{Cd}$ during vegetative growth and the relation with xylem sap composition. - Environmental Science and Pollution Research 23: 3152-3164.

[40] $\mathrm{R}$ development core team (2018): R: A language and environment for statistical computing. - $\mathrm{R}$ foundation for statistical computing, Vienna, Austria. URL http://www.R-project.org.

[41] Rai, P. K., Lee, S. S., Zhang, M., Tsang, Y. F., Kim, K.-H. (2019): Heavy metals in food crops: Health risks, fate, mechanisms, and management. - Environment International 125: 365-385.

[42] Rascio, N., Dalla Vecchia, F., Ferretti, M., Merlo, L., Ghisi, R. (1993): Some effects of cadmium on maize plants. - Archives of environmental contamination and toxicology 25 : 244-249.

[43] Raza, A., Habib, M., Kakavand, S. N., Zahid, Z., Zahra, N., Sharif, R., Hasanuzzaman, M. (2020): Phytoremediation of cadmium: Physiological, biochemical, and molecular mechanisms. - Biology 9: 177.

[44] Rehman, W., Zeb, A., Noor, N., Nawaz, M. (2008): Heavy metal pollution assessment in various industries of Pakistan. - Environmental Geology 55: 353-358.

[45] Retamal-Salgado, J., Hirzel, J., Walter, I., Matus, I. (2017): Bioabsorption and bioaccumulation of cadmium in the straw and grain of maize (Zea mays L.) in growing soils contaminated with cadmium in different environment. - International journal of environmental research and public health 14: 1399.

[46] Rizwan, M., Ali, S., Qayyum, M. F., Ok, Y. S., Zia-Ur-Rehman, M., Abbas, Z., Hannan, F. (2017): Use of maize (Zea mays L.) for phytomanagement of Cd-contaminated soils: A critical review. - Environmental geochemistry and health 39: 259-277.

[47] Rizwan, M., Ali, S., Ur Rehman, M. Z., Maqbool, A. (2019): A critical review on the effects of zinc at toxic levels of cadmium in plants. - Environmental Science and Pollution Research 26: 6279-6289.

[48] Rolli, N., Suvarnakhandi, S., Mulgund, G., Ratageri, R., Taranath, T. (2010): Biochemical responses and accumulation of cadmium in Spirodela polyrhiza. - Journal of environmental biology 31: 529-532.

[49] Roy, S. K., Cho, S.-W., Kwon, S. J., Kamal, A. H. M., Kim, S.-W., Oh, M.-W., Lee, M.S., Chung, K.-Y., Xin, Z., Woo, S.-H. (2016): Morpho-physiological and proteome level responses to cadmium stress in sorghum. - Plos one 11: e0150431.

[50] Roychowdhury, A., Datta, R., Sarkar, D. (2018): Heavy metal pollution and remediation. - Green chemistry, pp. 359-373.

[51] Shafi, M., Zhang, G., Bakht, J., Khan, M. A., Islam, U., Khan, M. D., Raziuddin, G. (2010): Effect of cadmium and salinity stresses on root morphology of wheat. - Pak J Bot 42: 2747-2754.

[52] Shah, T. R., Prasad, K., Kumar, P. (2016): Maize - a potential source of human nutrition and health: A review. - Cogent Food \& Agriculture 2: 1166995.

[53] Shareef, R. S., Mamat, A. S., Al-Shaheen, M. R., Ismaaiel, O. H. (2018): The effect of soil $\mathrm{pH}$ and cadmium on nitrogen, phosphorus and chlorophyll contents in corn (Zea mays L.). - J Adv Res Appl Chem. Eng 3: 12-17.

[54] Siebers, N., Godlinski, F., Leinweber, P. (2014): Bone char as phosphorus fertilizer involved in cadmium immobilization in lettuce, wheat, and potato cropping. - Journal of plant nutrition and soil science 177: 75-83.

[55] Singh, M., Srivastava, R. K. (2016): Feasibility of using tuberose (p. Tuberosa 1.) in horizontal subsurface flow constructed wetland for heavy metal removal from domestic wastewater. - Environmental Progress \& Sustainable Energy 35: 125-132.

[56] Singh, S., Reddy, V., Fleisher, D., Timlin, D. (2017): Relationship between photosynthetic pigments and chlorophyll fluorescence in soybean under varying phosphorus nutrition at ambient and elevated $\mathrm{CO}_{2}$. - Photosynthetica 55: 421-433. 
[57] Sitko, K., Gieroń, Ż., Szopiński, M., Zieleźnik-Rusinowska, P., Rusinowski, S., Pogrzeba, M., Daszkowska-Golec, A., Kalaji, H. M., Małkowski, E. (2019): Influence of short-term macronutrient deprivation in maize on photosynthetic characteristics, transpiration and pigment content. - Scientific reports 9: 1-12.

[58] Sparks, D. L., Helmke, P., Page, A. (1996): Methods of soil analysis: Chemical methods. - SSSA.

[59] Stritsis, C., Claassen, N. (2013): Cadmium uptake kinetics and plants factors of shoot Cd concentration. - Plant and Soil 367: 591-603.

[60] Trejo, N., Matus, I., Del Pozo, A., Walter, I., Hirzel, J. (2016): Cadmium phytoextraction capacity of white lupine (Lupinus albus L.) and narrow-leafed lupine (Lupinus angustifolius L.) in three contrasting agroclimatic conditions of Chile. - Chilean journal of agricultural research 76: 228-235.

[61] Van Slycken, S., Witters, N., Meers, E., Peene, A., Michels, E., Adriaensen, K., Ruttens, A., Vangronsveld, J., Du Laing, G., Wierinck, I. (2013): Safe use of metal-contaminated agricultural land by cultivation of energy maize (Zea mays). - Environmental pollution 178: 375-380.

[62] Waseem, A., Arshad, J., Iqbal, F., Sajjad, A., Mehmood, Z., Murtaza, G. (2014): Pollution status of Pakistan: A retrospective review on heavy metal contamination of water, soil, and vegetables. - BioMed research international 2014.

[63] Wuana, R., Okieimen, F. (2010): Phytoremediation potential of maize (Zea mays L.). A review. - African Journal of General Agriculture 6: 275-287.

[64] Yang, Y., Nan, Z., Zhao, Z. (2014): Bioaccumulation and translocation of cadmium in wheat (Triticum aestivum L.) and maize (Zea mays L.) from the polluted oasis soil of northwestern China. - Chemical Speciation \& Bioavailability 26: 43-51.

[65] Zhang, H., Zhang, L.-L., Li, J., Chen, M., An, R.-D. (2020): Comparative study on the bioaccumulation of lead, cadmium and nickel and their toxic effects on the growth and enzyme defence strategies of a heavy metal accumulator, Hydrilla verticillata (L.f.) Royle. - Environmental Science and Pollution Research 27: 9853-9865.

[66] Zhao, Y. (2011): Cadmium accumulation and antioxidative defenses in leaves of Triticum aestivum L. and Zea mays L. - African Journal of Biotechnology 10: 2936-2943.

[67] Zhou, J., Wan, H., He, J., Lyu, D., Li, H. (2017): Integration of cadmium accumulation, subcellular distribution, and physiological responses to understand cadmium tolerance in apple rootstocks. - Frontiers in Plant Science 8: 966. 


\section{APPENDIX}

\section{Supplementary information}

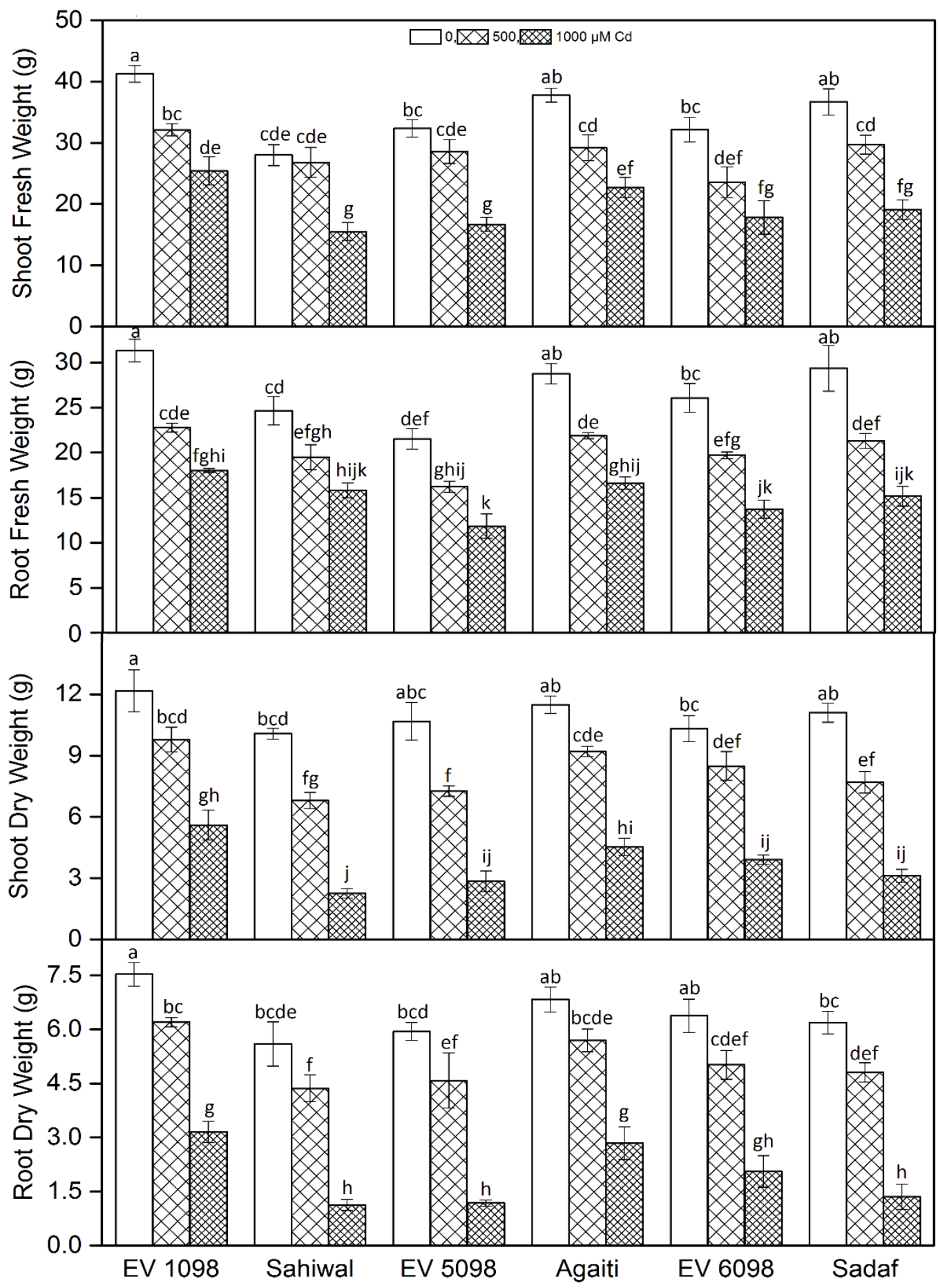

Figure S1. Effects of Cadmium (Cd) treatments on shoot fresh weight (SFW), root fresh weight $(R F W)$, shoot dry weight $(S D W)$ and root dry weight $(R D W)$ in the six maize cultivars. Bars (mean values $\pm S E$ ) having different letters show mean values that are significantly different

$$
(p<0.05)
$$




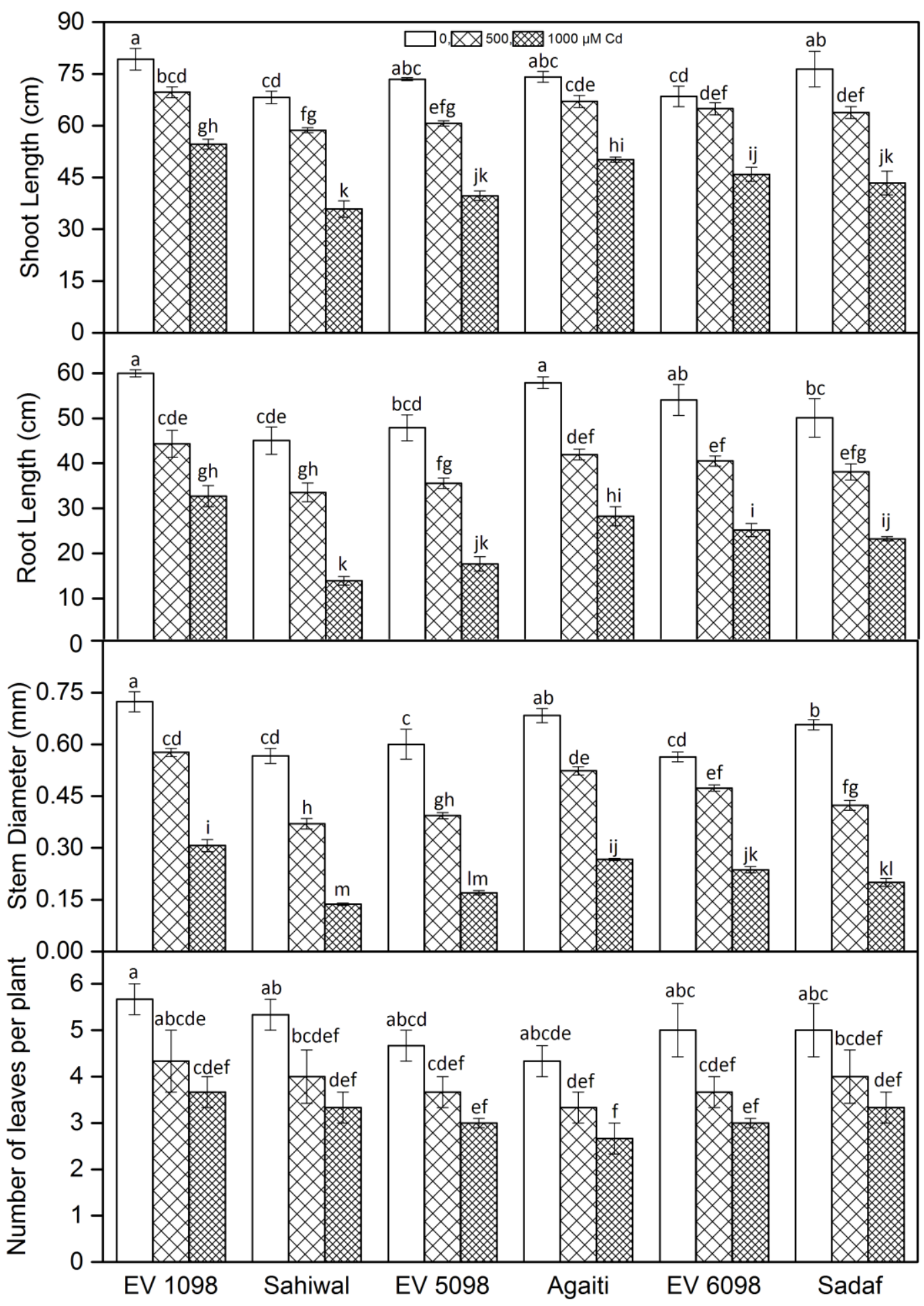

Figure S2. Effects of Cadmium (Cd) treatments on shoot length (SL), root length (RL), stem diameter $(S D)$ and number of leaves per plant (NOL) in the six maize cultivars. Bars (mean values $\pm S E)$ having different letters show mean values that are significantly different $(p<0.05)$ 

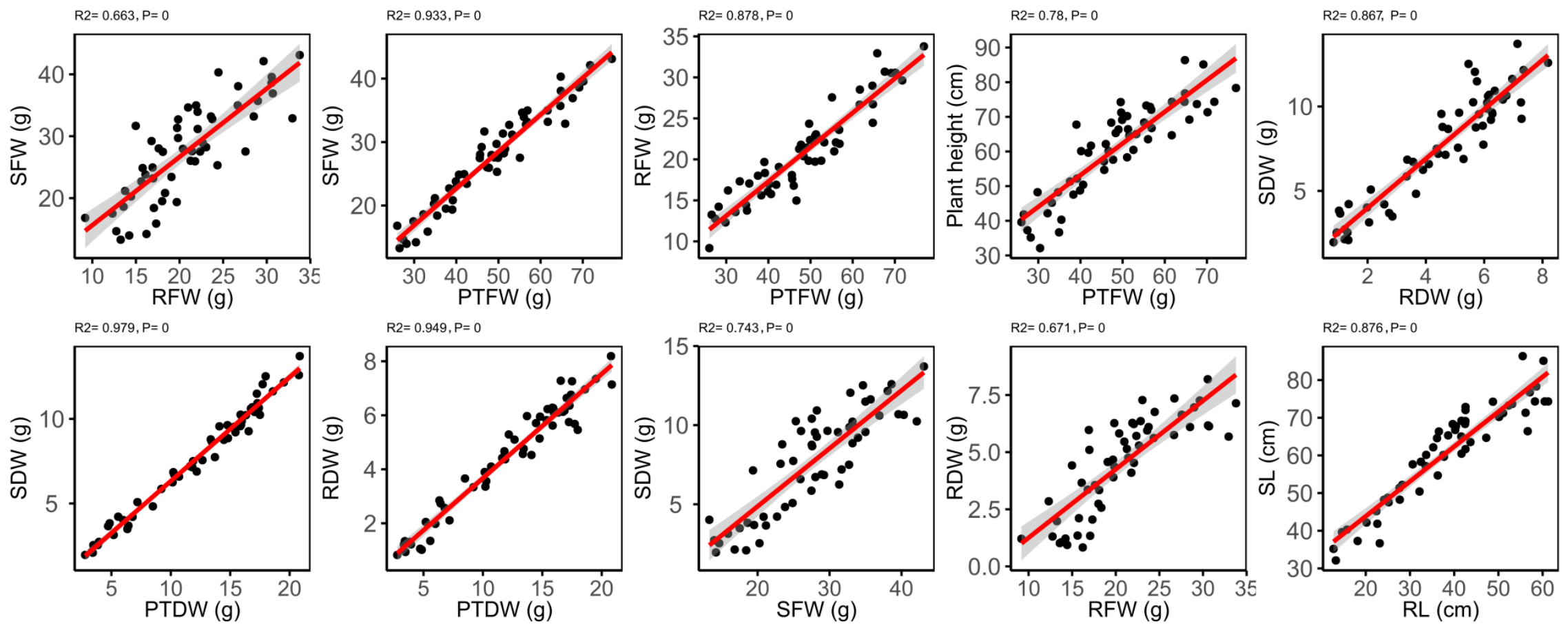

Figure S3. Relationship between shoot fresh weight (SFW), root fresh weight $(R F W)$, plant total fresh weight (PTFW), shoot dry weight (SDW), root dry weight $(R D W)$, plant total dry weight (PTDW), shoot length $(S L)$ and root length $(R L)$ 


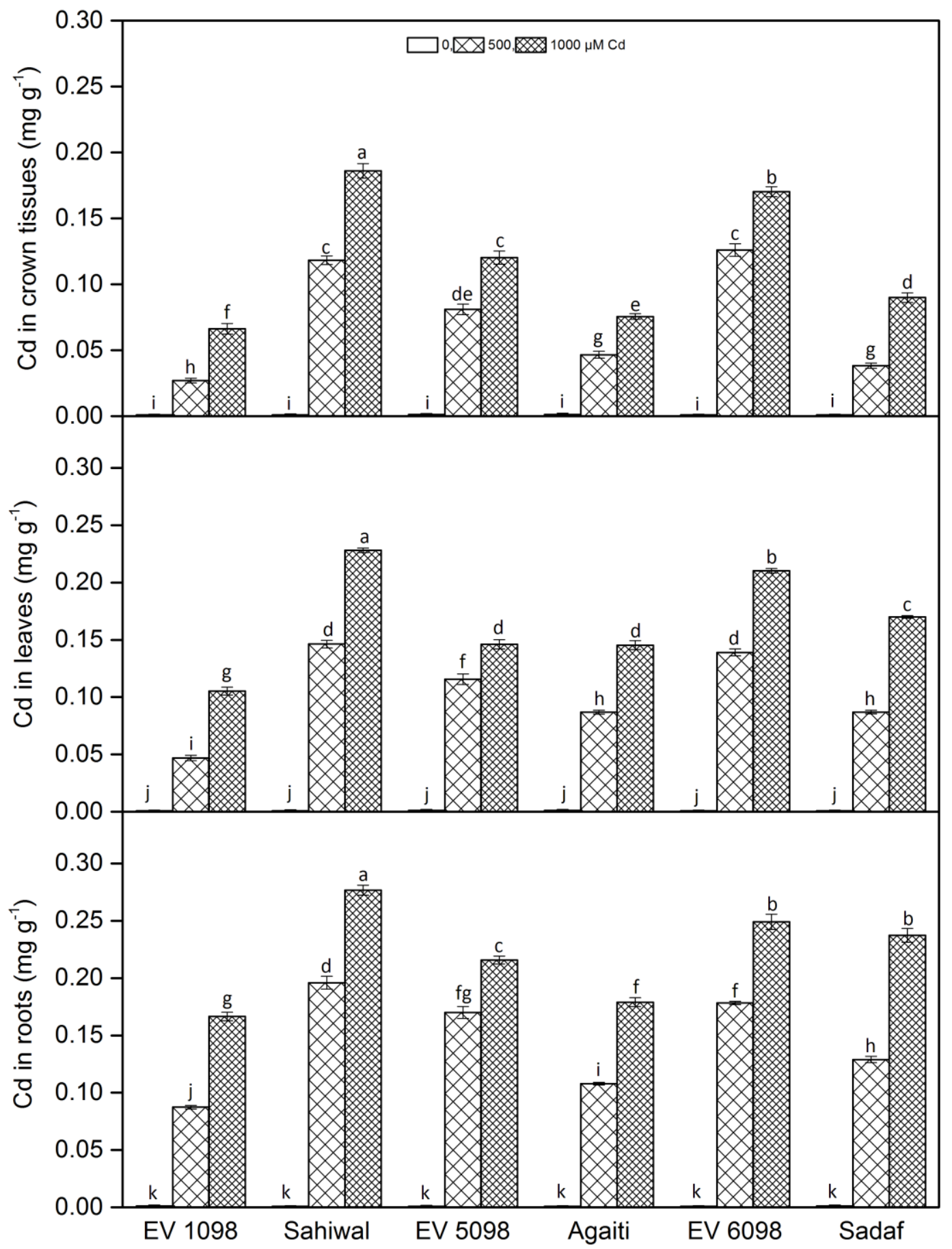

Figure S4. Cadmium $(C d)$ partitioning in the crown tissues, leaves and roots of six maize cultivars at three different $C d$ treatments (Mean $\pm S E$ ). Bars (mean values $\pm S E$ ) having different letters show mean values that are significantly different $(p<0.05)$ 

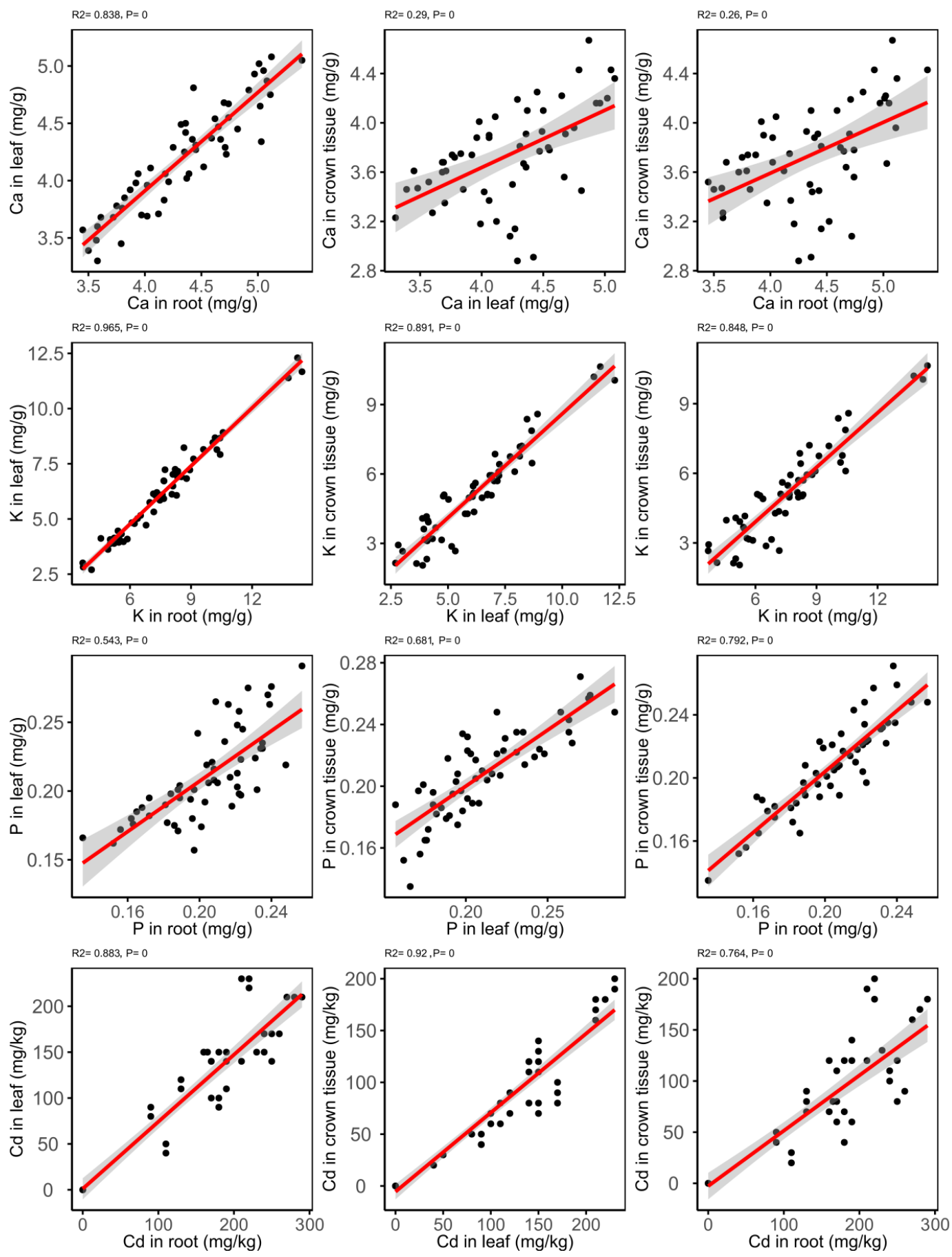

Figure S5. The relationships between Calcium (Ca), Potassium (K), Phosphorus $(P)$ and Cadmium $(C d)$ in the three different plant parts 